\title{
PSYCHO-SOCIAL ASPECTS OF RECOVERY FROM CORONARY HEART DISEASE: A REVIEW*
}

\author{
STEVEn R. Dofhrman† \\ Institute for Human Adjustment, University of Michigan
}

\begin{abstract}
The literature dealing with the psychological and social aspects of recovery from and rehabilitation to the acute onset of coronary heart disease (CHD) was reviewed. The papers published since an earlier review were placed into one of three categories: advocacy articles, generally describing psychological reactions of patients and advocating a particular treatment; clinical papers, dealing with impressionistic observations of the emotional state of patients and their spouses; empirical reports, exploring various scientific issues regarding social-psychological functioning. Research quality and quantity have increased greatly in the past eight years. There is little question that CHD results in the temporary disruption of normal psychological and social functioning. Long-lasting emotional distress, familial problems, and occupational maladjustment are observed in a significant minority of patients. Psychosocial counseling appears to facilitate and hasten rehabilitation. However, additional programmatic evaluation studies are required in order to assess which psycho-therapeutic procedures are essential and should be a routine part of treatment of acute CHD patients and their families.
\end{abstract}

The psychological and social problems resulting from coronary heart disease (CHD) are typically distressing and, for some patients, as debilitating as the primary illness itself [1]. However, literature published prior to 1968 neither fully identificd those social and psychological variables involved in the period following acute CHD nor elaborated upon their impact. In a comprehensive research literature review, Croog et al. [2] described some of the social-psychological aspects of recovery but concluded that "... the scientific study of these problems is still in its early stages" (p. 155; see also [3]). The present paper will review the literature published since the Croog et al. report. Its focus will be upon the social and psychological factors that are important during recovery and rehabilitation following the acute onset of CHD.

In contrast to the earlier review, relevant, nonresearch articles published since 1968 will also be included. This more inclusive approach leads to difficulties in attempting to compare conclusions of scientific researchers with impressions of practitioners. The standards of proof, or belief, are quite different in the two cases. It can even be argued that the two extremes, in fact, bear little relevance to one another. Yet, scientific findings should be considered by the practitioner and clinical observations should be considered by the scientist. To facilitate this dialogue, a wide range of papers is reviewed here. Initially, each paper was placed into one of three categories, in order of increasing scientific soundness: advocacy, clinical. or empirical. Advocacy articles deal with the exposi-

* This paper focuses upon one form of coronary heart disease: arteriosclerotic coronary artery disease. Except where indicated. the vast majority of references discussed herein pertain to the patient with myocardial infarction (MI).

† Now Clinical Psychologist. Psychological Clinic, and Lecturer. Department of Psychology. University of Michigan. Send requests for reprints to the author at: Psychological Clinic. 1027 E. Huron St.. Ann Arbor. MI 48104. U.S.A. tion of an opinion regarding some aspect of the treatment of the psychological distress of CHD patients. Clinical papers offer impressionistic observations of the emotional states of patients and family members. Empirical reports delve into a scientific examination of some issue regarding the social-psychological functioning of patients. In what follows below, the relevant literature for each category is discussed in turn. Because of differences in emphasis, it was not feasible to organize the presentation of each category in the same fashion. Whenever possible, comparisons among categories will be made.

A number of substantive areas only tangentially related to this review's focus were excluded. Possible social-psychological precursors to CHD have been recently considered by Jenkins [4] and will not be discussed. Other topics not covered below include: physiological functioning of CHD patients during sexual intercourse [5], emotional aspects of chronic myocardial ischemia [6-8], psychological reactions to cardiac surgery $[9,10]$, the experience of cardiac arrest [11], and psychosocial features of sudden death [12]. Kavanagh and Shephard [13] reviewed some of the literature on physical exercise programs for CHD patients [also see 14-25] but only those articles which evaluated concomitant psychological reactions will be discussed below. Papers since Croog et al. [2] which considered part of the relevant published literature include Hackett et al. [26], Miller and Brewer [27], Naughton and Bruhn [28], and Zohman [29].

\section{ADVOCACY ARTICLES}

The literature contains a number of papers focusing upon cmotional reactions and psycho-social counseling of CHD patients without emphasizing either empirical data or detailed clinical impressions. As such, these papers might best be thought of as advocacy articles that briefly describe a rehabilitation program, the role of a profession in treating CHD patients, or a specific component of treatment. In Table 1. each 
Table 1. A categorization for each advocacy article (see text) regarding the profession of the first author. a general brief description, substantive focus (i). and the relevant state of recovery

\begin{tabular}{|c|c|c|c|c|}
\hline $\begin{array}{l}\text { First author } \\
\text { (reference) }\end{array}$ & $\begin{array}{l}\text { Profession of } \\
\text { first author }\end{array}$ & $\begin{array}{c}\text { Brief } \\
\text { description }\end{array}$ & $\begin{array}{l}\text { Substantive } \\
\text { focus }(i)^{2}\end{array}$ & $\begin{array}{l}\text { Stage } \\
\text { of recovery }\end{array}$ \\
\hline Anderson $[30]$ & internal med & rehab program & ER. IPh. IT. Ed & Pust hospital \\
\hline Askanas $[31]$ & cardiologist & rehab program & IT, GA. Ed. PSC & Post hospital \\
\hline Baden [32] & nurse & teaching program & IN. Ed. F. ER & Post hospital \\
\hline Barry [33] & nurse & rehab program & IN. GA. Ed. F, ER & In hospital \\
\hline Bastiaans [34] & psychiatrist & $\begin{array}{l}\text { cardiac personality and } \\
\text { psychoanalytic therapy }\end{array}$ & ER. PSC & Post hospital \\
\hline Berg-Larsen [35] & psychiatrist & $\begin{array}{l}\text { psychodynamic evalu- } \\
\text { ations of patients }\end{array}$ & ER, PSC, OC & In hospital \\
\hline Bishop [36] & cardiologist & $\begin{array}{l}\text { psychological impact } \\
\text { of } \mathrm{CCU}\end{array}$ & ER. IPh & $\mathrm{CCL}$ \\
\hline Bishop [37] & cardiologist & $\begin{array}{l}\text { emotions in cardiac } \\
\text { patients }\end{array}$ & ER. IPh & $\mathrm{CCL}^{\prime}$ \\
\hline Bishop [38] & cardiologist & rehab program & IPh. ER. IT & Post hospital \\
\hline Borgman [39] & nurse & rehab program & Ed, IN, GA, PSC & CCL-post hospital \\
\hline Carnes $[40]$ & psychologist & $\begin{array}{l}\text { understanding the } \\
\text { cardiac personality }\end{array}$ & ER, PSC & In hospital \\
\hline Cassem [41] & psychiatrist & reactions to $\mathrm{CCU}$ nurse & IN, ER & $\mathrm{CCU}$ \\
\hline Cassem [42] & psychiatrist & $\begin{array}{l}\text { patient activity to } \\
\text { counter depression }\end{array}$ & GA. ER & CCU-post hospital \\
\hline Fejfar [43] & physician ${ }^{1}$ & rehabilitation & $\begin{array}{l}\text { IPh. IT. ER. Ed. PSC. } \\
\text { OC. GA }\end{array}$ & CCU-post hospital \\
\hline Foster [44] & nurse & care of MI patient & ER, PSC, IN & $\mathrm{CCU}$ \\
\hline Groden [45] & physician $^{1}$ & rehab program & OC. PSC. IT & Post hospital \\
\hline Hackett $[46]$ & psychiatrist & $\begin{array}{l}\text { medical treatment for } \\
\text { anxiety }\end{array}$ & ER. IPh & $\mathrm{CCL}$ \\
\hline Holub [47] & nurse & family conferences & F, ER & In hospital \\
\hline Houser $[48]$ & nurse & rehab program & Ed, ER, GA & CCL-post hospital \\
\hline $\begin{array}{l}\text { Kellerman [49] } \\
\text { Kos }[50]\end{array}$ & $\begin{array}{l}\text { physician }{ }^{2} \\
\text { nurse }\end{array}$ & $\begin{array}{l}\text { rehab program } \\
\text { rehab of MI patient }\end{array}$ & $\begin{array}{l}\text { GA. OC. ER } \\
\text { IN, ER, Ed, PSC }\end{array}$ & $\begin{array}{l}\text { Post hospital } \\
\text { In hospital }\end{array}$ \\
\hline Layman $[51]$ & psychiatrist & $\begin{array}{l}\text { psychological impact } \\
\text { of } \mathrm{CCU}\end{array}$ & ER, PSC & $\mathrm{CCU}$ \\
\hline Lee [52] & psychologist & $\begin{array}{l}\text { styles of emotional } \\
\text { adjustment }\end{array}$ & ER. PSC, F & $\mathrm{CCU}$ \\
\hline Lenzner [53] & psychiatrist & $\begin{array}{l}\text { psychosocial team in } \\
\text { every CCU }\end{array}$ & ER. PSC, IPs, IT & $\mathrm{CCU}$ \\
\hline $\begin{array}{l}\text { Nixon }[54,55,56] \\
\text { Rahe }[57]\end{array}$ & $\begin{array}{l}\text { cardiologist } \\
\text { psychiat rist }\end{array}$ & $\begin{array}{l}\text { rehab program } \\
\text { psychiatry on } \mathrm{CCU}\end{array}$ & $\begin{array}{l}\text { GA, PSC, Ed, ER } \\
\text { IPs, PSC, ER, Ed. } \\
\text { OC, F }\end{array}$ & $\begin{array}{l}\text { Post hospital } \\
\text { CCU }\end{array}$ \\
\hline Royle [58] & nurse & teaching program & Ed. ER, F, IN & CCU-post hospital \\
\hline Semmier [59] & $\begin{array}{l}\text { occupational } \\
\text { therapist }\end{array}$ & rehabilitation & $\begin{array}{l}\text { IOT. OC, Ed. GA, } \\
\text { ER. IT }\end{array}$ & CCU-post hospital \\
\hline Shah $[60,61]$ & cardiologist & rehab program & Ed, OC, PSC & CCU-post hospital \\
\hline Smith [62] & nurse & post MI body image & ER, PSC, F, IN & In hospital \\
\hline Sobel [63] & psychiatrist & personalized treatment & ER, PSC, IN & $\mathrm{CCU}$ \\
\hline Warshaw [64] & physician ${ }^{1}$ & joh placement & OC.GA, ER & Post hospiral \\
\hline White $[65]$ & nurse & $\begin{array}{l}\text { socio-emotional } \\
\text { aspects of nursing care }\end{array}$ & Ed, ER, IN, PSC & In hospital \\
\hline
\end{tabular}

${ }^{1}$ More specific information not available

${ }^{2} \mathrm{Ed}=$ education of patient re illness, medication, diet, activity

$E R=$ emotional reactions of patients

$F=$ family involvement in treatment

$\mathrm{GA}=$ graduated activity training of patient

$\mathrm{IN}=$ importance of nurse in treatment

IOT $=$ importance of occupational therapist in treatment

$\mathrm{IPh}=$ importance of physician in treatment

IPs $=$ importance of psychiatrist in treatment

$\mathrm{IT}=$ importance of team in treatment (team generally consists of some or all of the following: dietician. nurse. occupational therapist, physical therapist, physician, psychologist. social worker)

$\mathrm{OC}=$ occupational counseling of patient

PSC $=$ psycho-social counseling of patient

advocacy article is categorized according to the profession of the first author, a brief description of the paper, substantive focus (i), and the relevant stage of recovery of the CHD patient. An examination of the table indicates the published literature contains many professions advocating a variety of ideas with different foci relevant to the various stages of rehabilitation.

In order to consider general aspects of the specific references in Table 1 , the frequencies of the various publishing professions, foci, and recovery stages were determined. The frequencies refer to the published literature only and are clearly affected by the stated selection biases. Table 2 shows that members of four professions (or seven, considering medical specialities) authored papers. Physicians, presumably most of whom are practitioners, wrote $61^{\circ}$, with those specializing in psychiatry and cardiology being the most productive. Emotional reactions of patients (ER) received the most attention followed by specitic treatment approaches (PSC, Ed, GA) and professional role specifications (IN, IT, IPh). Occupational counseling (OC) and family involvement $(\mathrm{F})$ were the least mentioned approaches to treatment. In general, most papers dealt with a specific period of recovery with but eight of 36 papers considering the CHD patient 
Table 2. Frequency of occurrence in Table 1 of each profession. focus and stage of recovery

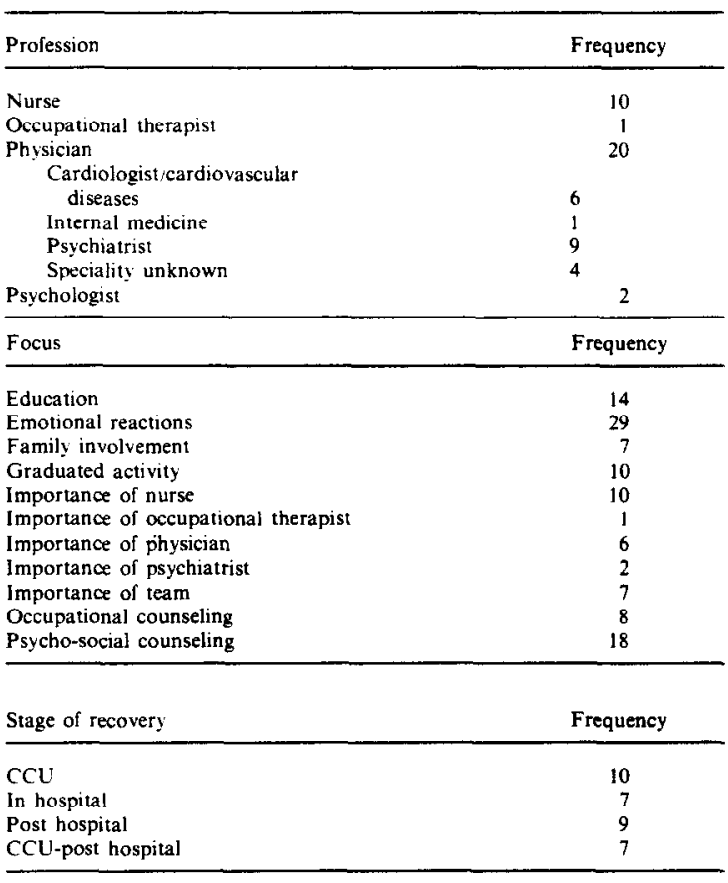

from entry into the coronary care unit (CCU) until after hospital discharge.

Only a few of the advocacy articles cite relevant empirical data and then typically only in the course of supporting the author's position on an issue rather than as a basis for exploring the issue itself. Hence, the papers must be considered mainly informational in that the interested reader, having consulted Table 1 , can further explore what is thought to be important regarding some aspect of psycho-social rehabilitation of the acutc CHD patient. A reading of the individual papers leaves one with the impression that they too often contain statements that are more emphatic and confident than is justified by currently available scientific data. Thus, the clinical and research papers discussed below may serve as a corrective to assertions lacking adequate empirical proof that have found their way into the professional literature.

\section{Clinical PaPERS}

Several articles report on contacts with MI patients and their spouses during the period of rehabilitation. An examination of Table 3 indicates that the nature and timing of the contacts varied greatly. Different professionals met with either patients or spouses of patients in either individual or group meetings occurring within a few days to as much as 1 year after the MI. Generally the interviews were said to be nondirective but, given the wide variety of information reported, it is reasonable to assume that the interviews were conducted in various styles by the several investigators. It must also be noted that the papers listed in Table 3 studied "verbal" patients who agreed to share their thoughts and feelings with the authors. Such a selected patient sample could have produced results not necessarily applicable to a more general patient population.

Table 3. A listing of papers reporting clinical observations and impressions of MI patients. Also provided are the profession of the first author, a brief description of the contacts and mention of additional information in each report

\begin{tabular}{|c|c|c|c|}
\hline $\begin{array}{l}\text { First author } \\
\text { (reference) }\end{array}$ & $\begin{array}{l}\text { Profession of } \\
\text { first author }\end{array}$ & Description of contacts & Additional information \\
\hline Adsett [66] & psychiatrist & $\begin{array}{l}\text { Separate patient and spouse } \\
\text { outpatient long-term } \\
\text { therapy groups, focus on imme- } \\
\text { diate problems and feelings }\end{array}$ & $\begin{array}{l}\text { Theme, group conflict, and } \\
\text { group solutions for each session; } \\
\text { Comparison of patient and spouse } \\
\text { groups. }\end{array}$ \\
\hline Bilodeau [67] & nurse & $\begin{array}{l}\text { A short-term therapy group of } \\
\text { outpatients. non-directive } \\
\text { supportive atmosphere }\end{array}$ & $\begin{array}{l}\text { Commonly raised issues and } \\
\text { patient reactions to group }\end{array}$ \\
\hline Idelson $[68,69]$ & not available & $\begin{array}{l}\text { Five individual multifaceted } \\
\text { interviews with patient and } \\
\text { spouse during first year post } \mathrm{MI}\end{array}$ & $\begin{array}{l}\text { Major stages of change in self- } \\
\text { concept during year; Tasks and } \\
\text { barriers in resocialization }\end{array}$ \\
\hline Karsten $[70]$ & $\begin{array}{l}\text { psychoanaly- } \\
\text { tically trained }\end{array}$ & $\begin{array}{l}\text { A therapy group of patients } \\
\text { seen during first two months } \\
\text { post MI, non-directive psycho- } \\
\text { analytic orientation }\end{array}$ & $\begin{array}{l}\text { Discussion of psychodynamics of } \\
\text { MI patients }\end{array}$ \\
\hline Klein [71] & physician & $\begin{array}{l}\text { Individual interviews with } \\
\text { hospitalized MI patients deal- } \\
\text { ing with feelings regarding } \mathrm{CCU} \\
\text { and transfer from it }\end{array}$ & $\begin{array}{l}\text { Five patient vignettes: } \\
\text { Suggested changes in CCU patient } \\
\text { care }\end{array}$ \\
\hline Lenzner [72] & psychiatrist & $\begin{array}{l}\text { Individual interviews with } \\
\text { CCU patients focusing upon } \\
\text { feelings and troubling thoughts }\end{array}$ & $\begin{array}{l}\text { Psychiatric vignettes of eight } \\
\text { patients }\end{array}$ \\
\hline Mone [73] & $\begin{array}{l}\text { psychiatric } \\
\text { social worker }\end{array}$ & $\begin{array}{l}\text { Problem-focused short-term } \\
\text { outpatient group therapy }\end{array}$ & Common group themes \\
\hline Ohlmeier [74] & psychotherapist & $\begin{array}{l}\text { Short-term group therapy with } \\
\text { recently discharged MIs, } \\
\text { psychoanalytic orientation }\end{array}$ & $\begin{array}{l}\text { Psychoanalytic configurational } \\
\text { analysis of each session }\end{array}$ \\
\hline Rahe $[75]$ & psychiatrist & $\begin{array}{l}\text { Short-term group therapy with } \\
\text { MI outpatients, dealing with } \\
\text { previous and present life } \\
\text { experiences }\end{array}$ & $\begin{array}{l}\text { Descriptions of six categories } \\
\text { of insight related to convalescent } \\
\text { experience; Four patient vignettes }\end{array}$ \\
\hline Skelton $[76]$ & social worker & $\begin{array}{l}\text { Individual interviews with } \\
\text { spouses of MIs during first } \\
\text { year post MI, exploration of } \\
\text { spouses' (wives') feelings }\end{array}$ & $\begin{array}{l}\text { Frequency count of affective } \\
\text { reactions and familial problems } \\
\text { as function of time since } \mathrm{Ml}\end{array}$ \\
\hline Tyzenhouse [77] & nurse & $\begin{array}{l}\text { One home interview with spouse } \\
\text { one year post MI }\end{array}$ & $\begin{array}{l}\text { Mention of various familial } \\
\text { reactions to patient illness }\end{array}$ \\
\hline
\end{tabular}


The clinical papers reported relatively consistent impressions of the difficulties in rehabilitation from acute CHD. For the samples studied, some general summary statements can be made. Patients have intense emotional reactions to their illness which subside only after a period of months $[66-77]$. They express fears of recurrence and possible death from a second MI $[66,67,70,75]$. The loss of self-esteem $[66,67]$ can bring about depression and a reorganization in the sense of self that is generally accomplished within a year $[68,69]$. Diminished libido, if not impotence, is not uncommon $[67,73]$ and may be caused by a fear of death during intercourse and by decreased self-regard.

Conflicts between patients and family members focus upon the patient's diet, medication and physical activity [67,75-77]. Typically, patients resent the overprotectiveness and concern shown them by their wives and families and, instead, they attempt to dominate others when they return home $[66,67,70,75-77]$. Wives, feeling guilty about their husbands' $\mathrm{MI}$ and fearing a recurrence of it $[67,76]$, become solicitous, in some cases overly so, in order to avoid arguments and unpleasant situations $[66,76,77]$. The most stressful period for the recovering patient is probably about 4 months after hospital discharge $[68,69]$ when, no longer sick and yet not completely recovered, the patient begins the difficult process of returning to work [75].

None of the papers in Table 3 which reported psychotherapeutic contact with patients or spouses incorporated an evaluation of the treatment. However. three additional investigations of treatment programs for MI patients did involve a research evaluation including a no-treatment control group. Ibrahim et al. [78] compared patients offered group therapy for 1 year following an $\mathrm{MI}$ with control patients receiving only routine medical care. An attendance rate of $69 \%$ for the group meetings supports the feasibility of such treatment. Although there were no significant differences between the therapy and control groups on physiological and psychological factors, the findings suggested that the therapy patients have a better survival experience, less social alienation and shorter periods of rehospitalization than controls.

A study by Thockloth et al. [79] found that patients who had regular contacts with an occupational therapist and with a social worker for 6 months following an MI felt significantly better and were judged to have undergone more successful occupational adjustment than controls. Although the findings support the efficacy of individual psychotherapeutic contact with MIs, it must be pointed out that this study did not avoid potential contaminating factors. For example, therapy patients might have been inclined to overstate their well-being and investigators to misperceive their supportive efforts. As Greene [80] argues, placebo effects and other biases need to be controlled in order to conduct scientifically sound intervention treatment trials.

In a well-conceived study, Gruen [81] intensively counseled hospitalized MI patients to cope with their illness by relying upon their psychological resources. Treated patients were superior to untreated control patients in a number of objectively assessed psychological variables. i.e. less depression. less anxiety, fewer residual fears and greater ability to return to work; and on several medical outcome measures. i.e. fewer days in intensive care and in the hospital. less frequent development of supraventricular arrhythmias and of congestive heart failure. and fewer nurses" observations of weakness.

In summarizing the clinical papers since the Croog et al. [2] review, several of them. as noted above, have expanded upon the knowledge of the intrapsychic states and interpersonal relationships of the recovering MI patient. Of the many studies reporting psychotherapeutic work with MI patients and their spouses $[66,67,70.73-75,78,79,81,82]$ all reported beneficial effects and some [78.81] had objective data to support the contention. Ibrahim [83], in a review of some of the above literature, legitimately concluded that group therapy for MI patients is useful and should be explored further. Also. the study of Gruen [81] indicates the efficacy of individual treatment. There is a need for more investigators to include a built-in assessment of the reliability and validity of the impressionistic judgments which form the foundation of their studies. The observation that MI patients are more resistant to self-exploration than typical therapy patients merits empirical examination. Given the present state of knowledge, it is most important to evaluate empirically the relative effectiveness of various psychotherapeutic regimens in reducing emotional distress and facilitating recovery of $\mathrm{CHD}$ patients.

\section{EMPIRICAL REPORTS}

Investigations reporting objective empirical data on social or psychological variables have studied patients at widely different times after the onset of acute CHD, ranging from less than 2 hours to almost two decades. Although longitudinal studies would provide unique information, most researchers have focused their attention on relatively narrow time spans, a few weeks or months, following the acute incident. The review of most of this literature will be organized along the temporal dimension. according to the relevance to the pre-hospital, hospital, or post-hospital period. A later section examining the interrelationship between physiological functioning and psychological functioning will use a longitudinal approach.

\section{Pre-hospital}

It is estimated that over one-half of all deaths following myocardial infarction occur within the first 4 hours [84]. Thus, a reduction in the time between symptom onset and arrival at the hospital emergency unit would presumably be of benefit to the patient. Five papers [85-89] have studied the relationship between DHAT (delay in hospital arrival time) and a number of demographic. social, psychological and medical factors. Patient interviews and hospital records were the sources of data. The studies considered randomly selected patients of all ages, i.e. 35-75 years, who were admitted to emergency units of large hospitals in or near metropolitan areas of the United States with a probable. later verified. diagnosis of myocardial infarction. The summary conclusions derived from the five studies apply only to populations with similar characteristics. 
Table 4. Findings ${ }^{1.2}$ from five studies which examined the time involved between symptom onset of acute MI and hospital arrival as a function of demographic, social. psychological, and medical factors

\begin{tabular}{|c|c|c|c|c|c|c|c|c|c|}
\hline & Goldstine [85] & Hackett [86] & Moss [87] & Moss [88] & Simon [89] & \multicolumn{4}{|c|}{ Composite } \\
\hline \multirow{2}{*}{$\begin{array}{l}\text { Number of subjects } \\
\text { Mean times for: }\end{array}$} & 71 & 88 & 64 & 160 & 160 & & & & \\
\hline & & & & & & & & & \\
\hline Decision & $170 \min$ & NR & $200 \mathrm{~min}$ & $453 \mathrm{~min}$ & NR & & & $74 \mathrm{r}$ & $\min$ \\
\hline Transportation & NR & NR & $29 \mathrm{~min}$ & $25 \mathrm{~min}$ & about $25 \mathrm{~min}$ & & & 26 & min \\
\hline Unaccounted for & $111 \mathrm{~min}$ & NR & $77 \mathrm{~min}$ & $280 \mathrm{~min}$ & NR & & & 56 & $\min$ \\
\hline DHAT & $285 \mathrm{~min}$ & $636 \mathrm{~min}$ & $306 \mathrm{~min}$ & $758 \mathrm{~min}$ & $\mathrm{NR}$ & & & 96 & $\min$ \\
\hline Median DHAT & $150 \mathrm{~min}$ & $234 \mathrm{~min}$ & NR & $210 \mathrm{~min}$ & $165 \mathrm{~min}$ & & & $90 \mathrm{r}$ & $\min$ \\
\hline Demographic factors & & & & & & + & -0 & 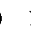 & NR \\
\hline Age (older) & NR & 0 & + & 0 & 0 & 1 & 0 & 3 & 1 \\
\hline Sex & NR & 0 & 0 & 0 & 0 & 0 & 0 & 4 & 1 \\
\hline Socioeconomic status & NR & 0 & NR & NR & 0 & 0 & 0 & 2 & 3 \\
\hline Educational level & NR & NR & 0 & 0 & 0 & 0 & 0 & 3 & 2 \\
\hline $\begin{array}{l}\text { Social-psychological } \\
\text { factors }\end{array}$ & & & & & & + & -0 & & NR \\
\hline Symptom onset time: & & & & & & & & & \\
\hline Day & NR & NR & 0 & NR & 0 & 0 & 0 & 2 & 3 \\
\hline Night & NR & NR & 0 & - & 0 & 0 & 1 & 2 & 2 \\
\hline Weekday & NR & NR & - & 0 & NR & 0 & 1 & 1 & 3 \\
\hline Weekend & NR & NR & + & 0 & NR & 1 & 0 & 1 & 3 \\
\hline At work & - & NR & NR & NR & NR & 0 & 1 & 0 & 4 \\
\hline Not at work & + & NR & NR & NR & NR & 1 & 0 & 0 & 4 \\
\hline Patient impression: & & & & & & & & & \\
\hline Angina & + & 0 & - & 0 & + & 2 & 1 & 2 & 0 \\
\hline Indigestion & 0 & 0 & + & 0 & NR & 1 & 0 & 3 & 1 \\
\hline Ml & 0 & NR & - & 0 & NR & 0 & 1 & 2 & 2 \\
\hline Unknown & 0 & NR & + & NR & NR & 1 & 0 & 1 & 3 \\
\hline Symptoms: & & & & & & & & & \\
\hline Extent of severity & NR & - & NR & NR & NR & 0 & 1 & 0 & 4 \\
\hline Displacement away from & & & & & & & & & \\
\hline heart & NR & + & NR & 0 & NR & 1 & 0 & 1 & 3 \\
\hline Denial of fear anxiety & NR & 0 & NR & NR & NR & 0 & 0 & 1 & 4 \\
\hline Decision made with/by: & & & & & & & & & \\
\hline Patient alone & + & - & 0 & - & NR & 1 & 2 & 1 & 1 \\
\hline Patient with relative? & & & & & & & & & \\
\hline friend & - & + & 0 & + & NR & 2 & 1 & 1 & 1 \\
\hline Patient with stranger & NR & - & 0 & 0 & NR & 0 & 1 & 2 & 2 \\
\hline Transportation: & & & & & & & & & \\
\hline Satellite CCU & - & NR & NR & NR & NR & 0 & 1 & 0 & 4 \\
\hline Ambulance $(-)$ vs. car $(+)$ & NR & NR & - & - & - & 0 & 3 & 0 & 2 \\
\hline Medical factors & & & & & & + & - & 0 & NR \\
\hline Previous history: & & & & & & & & & \\
\hline Angina & + & NR & 0 & + & NR & 2 & 0 & 1 & 2 \\
\hline Congestive heart failure & NR & NR & 0 & 0 & NR & 0 & 0 & 2 & 3 \\
\hline Diabetes & 0 & NR & NR & + & NR & 1 & 0 & $i$ & 3 \\
\hline Hypertension & 0 & NR & 0 & 0 & NR & 0 & 0 & 3 & 2 \\
\hline MI & 0 & 0 & 0 & 0 & 0 & 0 & 0 & 5 & 0 \\
\hline Ulcer & - & NR & NR & NR & NR & 0 & 1 & 0 & 4 \\
\hline Medical judgment & & & & & & & & & \\
\hline of symptom severity & NR & 0 & NR & NR & NR & 0 & 0 & 1 & 4 \\
\hline Patient took prescribed & & & & & & & & & \\
\hline medications & NR & NR & NR & NR & + & 1 & 0 & 0 & 4 \\
\hline Patient took patent & & & & & & & & & \\
\hline medications & NR & NR & NR & NR & + & 1 & 0 & 0 & 4 \\
\hline Patient contacted physician & $\mathrm{NR}$ & +3 & NR & NR & + & 2 & 0 & 0 & 3 \\
\hline Complications in CCU: & & & & & & & & & \\
\hline Arrhythmia & NR & NR & 0 & 0 & NR & 0 & 0 & 2 & 3 \\
\hline Hypotension & NR & NR & 0 & 0 & NR & 0 & 0 & 2 & 3 \\
\hline Congestict heart failure & NR & NR & + & NR & NR & 1 & 0 & 0 & 4 \\
\hline Cardiac arrest & NR & NR & 0 & NR & NR & 0 & 0 & 1 & 4 \\
\hline Mortality in hospital & NR & NR & NR & + & 0 & I & 0 & 1 & 3 \\
\hline
\end{tabular}

${ }^{1}$ The different papers presented their data in different fashions. One study [88] reports results in terms of decision time. two [86.89] use DHAT, another [85] provides both DHAT and decision time, and the remaining one [87] presents DHAT for all factors except CCU complications, for which decision time is reported. However, since decision time constitutes $60 \%$ [88] to $65 \%$ [87] of DHAT the findings using the two different measures should be comparable.

In addition. the relationship between the different factors and the times was determined by three different approaches: (1) A comparison of DHAT of patients having a large degree of a factor with DHAT of patients having a small or no degree of a factor [86,87,89]; (2) The proportion of patients with long DHAT or decision time who have a factor as compared to the proportion of patients with short DHAT or decision time who have the same factor; (3) A comparison of decision time of patients having one factor with patients having another factor, e.g. decision time for patients with a history of angina vs decision time for patients with a history of hypertension. To facilitate comparison of these data [85] with those from other papers and to address the issue of which factors are related to an increase or decrease in DHAT. the published findings were reanalyzed. The table lists whether or not the mean DHAT for a given factor was within one standard deviation of the overall mean DHAT.

${ }^{2}$ Definition of symbols: $\mathrm{NR}=$ data not reported; $+=$ factor related to increased DHAT or decision time; $-=$ factor related to decreased DHAT or decision time; $0=$ factor not related to a change in DHAT or decision time.

${ }^{3}$ Physicians were involved in the delay of $12 \%$ of the cases in the study. 
Table 4 presents the findings regarding estimates of DHAT and other time intervals as well as the relationship, if any, between the various factors and DHAT. Although the five studies did not examine all of the same factors using the same statistics and statistical tests, the composite column in Table 4 gives the key findings. Mean DHAT is $496 \mathrm{~min}$ whereas median DHAT is only $190 \mathrm{~min}$-an indication that while half the arrivals occur within 3 hours, many are delayed as much as 8 hours and even longer. Hence, nearly $40 \%$ of all patients arrive at the hospital after the period of greatest mortality has elapsed.

Increased DHAT is unrelated to demographic factors, i.e. not to age, sex, socioeconomic status or education level [86-89]. The results with respect to social-psychological factors are mixed and not very definitive. Longer DHAT was associated with not being at work [85], with the patient having the impression of angina symptoms [85,89, but not 87], with being transported to the hospital by car and not by ambulance. The last finding is not a consequence of increased transportation time [89] but apparently is related to a judgment that the symptoms are severe, a factor which results in shorter DHAT [86]. The data in regard to the presence of other persons who might influence the decision to go to the hospital are contradictory [see 85-88]. Also, denial by the patient of fear or anxiety did not lengthen DHAT [86].

The relationship between medical factors and DHAT were more definitive but no less surprising than the above. The data with regard to a decline in mortality with short DHAT are inconclusive-one study [83] showed shorter decision time associated with lower mortality whereas another [89] found no facilitative effect of shorter DHAT upon survival. Patients with a history of angina are more likely to have longer DHATs than patients without such a background $[85,88]$. Similarly, a previous MI definitely does not shorten DHAT for a following episode [85-89]. In addition, patients who took medications or contacted their doctors had increased DHATs over those who did neither $[86,89]$. Shorter DHAT was not, in general, related to fewer complications in the CCU $\lceil 87,88\rceil$.

In sum, demographic, social and psychological factors were not generally or systematically found to be related to DHAT. This conclusion is unexpected given that $55 \%$ of DHAT is made up of decision time $[85,87,88]$, a component that, apparently, should be related to personal characteristics of the patient. Future research examining a wider variety of psychosocial characteristics might have a better chance of isolating factors correlated with DHAT. It would also be useful to study a comparison group of patients who came to a $\mathrm{CCU}$ but were later diagnosed as not having CHD. Such a procedure would make it possible to determine if there is a type of person who incorrectly, rather than too reluctantly, acts on the self-perception of acute heart symptoms.

The major conclusion that can be reached about factors related to the time of arrival at a hospital following acute MI symptom onset concerns previous medical history. The data show that the only easily identifiable subgroup of patients who were not early arrivals, and who should have been, were those who had a past history of cardiac problems. Therefore. an education program is necessitated which instructs previous MI patients about seeking medical attention promptly when symptoms develop rather than depending wholly upon their medication. At the same time, it will also bc important to direct educational materials toward prospective patients most at risk so as not to flood hospital emergency units with people not in need of emergency services [91].

Further investigators of this topic would also do well to study patient populations without easy access to hospital care, e.g. people living in rural areas of the U.S. or other nations.

\section{Hospital}

Admission to a hospital is a clearcut acknowledgement by an acute CHD patient and by medical personnel of the catastrophic nature of the physical illness. In addition to being the first step toward recovery (for most patients), hospital admission brings about a drastic change in daily living and would be expected to have social-psychological ramifications. even aside from those induced by physiological factors.

Psychological reactions to the hospital enviromment. Eight papers considered the extent of emotional distress brought about by $\mathrm{CCU}$ equipment, activities and procedures [92-99]. One study [92] reported that only four of $39 \mathrm{MI}$ patients who had been administered the last rites of their religion were negative about the experience. Hackett et al. [93] found little. if any, serious psychological upset caused by what might be considered provocative circumstances, e.g. being attached to a monitor or witnessing the cardiac arrest of another patient. On the other hand, Bruhn et al. [94] reported differences in psychological and physiological reactions between $\mathrm{CCU}$ patients who witnessed the sudden death of another patient and $\mathrm{CCU}$ patients who did not observe any critical events. The experimental group showed a significant increase in systolic blood pressure followed by a significant decline $48 \mathrm{hr}$ later and, also, a temporary increase in judged anxiety. The control patients evidenced no changes in blood pressure or anxiety. Graham [95] found that $93 \%$ of their patients rated their CCU care as excellent and attributed their secure feelings to the monitoring equipment and nursing assistance. Cay et al. [96] reported that a psychiatrist judged $88 \%$ of a CHD patient sample to be reassured by the CCU with only $12 \%$ indifferent to or upset by it. The authors concluded that psychiatric reasons were responsible in the cases of patients not reassured by the CCU. In a similar investigation. Dominian and Dobson [97] reported $43 \%$ of their CHD patients reassured by the $\mathrm{CCU}$ with $49 \%$ experiencing it with neutral affect and $8 \%$ finding it to be anxiety-provoking. Furthermore, both seriously ill patients and lower class patients were significantly less likely to be reassured by the unit than less ill patients and middle or upper class patients. Psychiatric history was unrelated to patient attitudes. Parker and Hodge [98] claim that the delirium experienced by a group of $\mathrm{CCU}$ patients they studied was related to conditions of sensory monotony and sleep deprivation. Leigh et al. [99] compared affect states of patients in an open ward with those in a closed ward. Not surprisingly. 
there was a great deal more human interaction in the open ward. More importantly, the closed ward, as compared to the open ward, did not result in reduced patient anxiety levels, but rather in somewhat higher levels.

There were scientific shortcomings in some of the above work. Only two studies used a control group so as to provide a relative comparison of patient attitudes rather than relying on absolute percentages of judgments that varied greatly from one report to the next [cf. 95 and 97]. Biases [80] affected the selection of patients and the conduct of interviews-patients over 60 or with below average intelligence or subnormal psychological adjustment were excluded in one study [95], interviews were ended at the first sign of distress in another [93] -and, hence, probably distorted the findings. Finally, it is not at all clear on what basis a CCU patient, or a psychiatrist, makes the judgment as to what is causing the patient's emotional distress. Two sets of investigations - [93] and [100], [96] and [101]-claimed, without adequate comparison groups, that the observed psychological upset was caused by the illness, not by the CCU.

In conclusion, there is little indication that CCU equipment, activities, or procedures bring about longlasting psychological disturbances in modal CCU patients in British, Scottish and American hospitals. More sophisticated scientific research is needed, however, to make this conclusion more solid and more widely applicable. Likewise, the individual differences in emotional reactions [99] that may be related to social class and illness severity [97], if not previous psychiatric history [96, but not 97], merit further study. Eventually, patients might be better matched to more personally suitable hospital environments.

Quality and temporal course of emotional distress. The presence of emotional distress in unselected CHD patients newly admitted to an American [100] and to a Scottish [101] hospital was considered in two studies. Cay et al. [101] interviewed patients 8-10 days after a diagnosed episode of either MI or myocardial ischemia. It was judged that $62 \%$ of the MIs showed evidence of some emotional upset, with the predominant symptoms being anxiety or depression. Seventy per cent of patients diagnosed with myocardial ischemia were judged to be upset. Cassem and Hackett [100] reported that $33 \%$ of patients admitted to a CCU were referred by nurses or physicians for psychiatric consultation. Part of the discrepancy between the two studies can be attributed to different criteria for psychological distress-some emotional upset [101], need for psychiatric consultation [100]. Although it might also be argued that the absolute percentages could have been affected by biases and other factors [80], it can be safely concluded that at least a substantial minority of acute $\mathrm{CHD}$ patients experienced a significant degree of emotional distress while in the CCUs of the hospitals studied. More research is needed to determine if this conclusion is applicable to patients in other hospitals and in other countries.

The Cassem and Hackett [100] paper developed a model for the time course of emotional reactions of a person who has an MI. The reasons for psychiatric referral as a function of time since the acute incident were assumed to be indicative of the normal reactions of the typical patient. That is, the patient feels heightened anxiety during the first 2 days after the MI and shortly thereafter becomes depressed for a few more days. Reacting to his strong emotions, the patient denies the seriousness of his illness and, as a result, becomes somewhat difficult to manage.

Four studies [102-105] collected data which are directly relevant to the Cassem and Hackett model. Affect states were assessed using objective tests or clinical judgments [106-109]. There was good support for the proposition that anxiety, initially at a high level, declines within 5 or 6 days following the MI [102-104]. No study found a significant change in depression while patients were in the CCU [102-104]. There was a suggestion in one paper [105] that deniers, defined as those who do not acknowledge that they have had a heart attack, were more likely to resist following medical advice than nondeniers.

An implicit notion of the Cassem and Hackett model [100], explicitly stated in the Hackett and Cassem [107] paper, is that the MI patient, by denying the fear, if not the reality, of his heart attack, avoids the anxiety and depression associated with nondenial. Two further corollaries are that deniers live longer, and that denial is related to the seriousness of the illness. The relevant empirical data for each of these three assertions will be considered in turn.

Two investigations found deniers to be less anxious than non-deniers $[102,110]$, whereas a third found no differences in anxiety as a function of degree of denial [103]. Further, depression and denial were unrelated in all three studies that examined the relationship between the two affect states $[102,103,110]$.

Although the denial-longevity hypothesis has been frequently mentioned in the literature-e.g. $[26,56,103,109,110]$-only two reports have offered empirical data relevant to it- $[93$ and 102]. Gentry et al. [102] found that the two deaths which occurred in their 16 person sample were of non-deniers, and Hackett et al. [93] report that one-half of the four deaths in their sample of 50 patients were of minimal deniers. Neither study had enough participants to properly apply statistical tests.

Two papers compared the amount of denial among patients with different diseases [111,112]. Hackett and Weisman [111], assessing denial with objective and subjective items, found no differences in denial between heart patients and cancer patients. The findings were contrary to the investigators' expectation that heart patients, having a more favorable prognosis than cancer patients, would use denial more often. In another study, Levine and Zigler [112] reasoned that the degree of denial is positively related to the extent that the physical illness threatens the self. They compared groups of stroke, lung cancer and heart usease patients on the degree of denial, which was defined as the amount of discrepancy between the real self-image and the ideal self-image-the smaller the discrepancy, the greater the denial. The data supported the hypothesis that patients with more severe illness use more denial, and contradicted the contrary hypothesis of Hackett and Weisman [111] that denial and illness severity are inversely related. However, additional findings which showed that denial was unrelated to the observed low degree of satisfaction with 
health [112], suggest that denial was not that effective for any of the patient groups.

In sum, the Cassem and Hackett [100] model has received only partial empirical support in the samples studied. all from American hospitals. The patient is generally quite anxious for a few days following an MI, but does not become depressed while in the CCU [102-104]. The patient who denies the seriousness of his illness may be less anxious than the patient who does not deny $[102,110$, not 103$]$ but the direction of causality is unclear. It appears that denial is positively related to illness severity [112], a finding which is inconsistent with the unverified denial-longevity hypothesis. One striking difference between the clinical papers mentioned above and the research reports under discussion is the relatively greater emphasis in the latter upon the role of denial as a focal psychological mechanism for the recovering MI patient [see also 113]. An empirically testable explanation [63] for this phenomenon is that MI patients avoid troublesome feelings about their illness during brief interviews and while taking paper-and-pencil tests but that during intensive personal contacts in a supportive environment they more easily delve into emotionally distressing issues.

Social factors. Perhaps because of greater importance later in the recovery process, little effort has been directed toward considering social factors and the hospitalized patient. Cay et al. [101] reported that, at discharge, $42 \%$ of unselected $\mathrm{CHD}$ patients in a Scottish hospital anticipated social problems when they returned home, with one third of the problems expected to be of a serious nature. The substantive problem areas were related to employment, family or marriage, and finances. Croog and Levine [114] found that less educated American MI patients more often reported no discussion with their physician about the effects their illness would have upon future employment and physical exertion. In a similar vein, Dominian and Dobson [97], as mentioned above, found British lower class patients to be the least reassured by the hospital environment. It appears that social factors, such as social class and employment opportunities, might be related to a patient's view of his life in the hospital and his attitudes towards the future. Since feelings and opinions of hospitalized patients might greatly influence subsequent behaviors, perhaps differentially as a function of various social factors, more empirical attention to these issues is necessitated.

\section{Post-hospital}

Published reports dealing with the post-hospital phase following acutc CHD fall into threc broad categories: psychological and social factors, occupational adjustment, and mortality. Each category will be considered in turn with the aid of tables which summarize the methods and findings of relevant papers. The tathles may be viewed as pertinent to three dimensions of long-term outcome: psychological and social (Table 5), occupational (Table 6), and physiological (Table 7).

Psychological and social factors. A great deal of emotional distress was observed in post-hospital patients (see Table 5). Interviewer judgments of distress ranged from $20 \%$ of patients [122] to $88 \%$ of patients [131]. with remaining papers $[132.115$ and $125]$ reporting 50.56 and $69^{\circ}$, respectively. Wide differences among reports of emotional distress could be due to differences in the populations studied and/or to the crudeness and imperfect validity of dichotomous impressionistic judgments. Even so, if time since acute CHD onset is considered, then the extent of distress declines-88-69-20 ${ }^{\circ}$ - as time since the incident increases from 2 months to 2 years (the time of the interviews in Wynn [132], and Brown et al. [115], were not given).

Examination of data collected in research investigations using the MMPI [128] provides information about the type of distress experienced by the post-discharge patient. All seven studies reporting MMPI results found that patient samples deviated from published norms $[82,121,124]$ or tested controls $[116,117,126,128,129]$. Typically, the differences were on the neurotic triad [133]: hypochondriasis $[82,121,126,129]$, depression $[121,124,126,128$, 129], and hysteria [82.121. 126, 129]. Three papers $[116,117,128]$ reported that patients were also abnormally higher than controls on the MMPI anxiety scale, with one study [128] demonstrating that patients were abnormally anxious as long as 5 years after hospital discharge. The trend seen above regarding psychological distress as a function of time since the acute incident cannot be examined for the MMPI studies since most of the latter tested patients at widely different and unspecified times. Among the other affective and cognitive measures, only the Eysenck MPI scale $[82,123]$ showed a difference in the expected direction between patient and control groups.

The relationship between various psycho-social variables and later emotional maladjustment was considered in a few studies. The patient's perception of his health was found to be positively related to morale [120]; medical status was related to psychological adjustment in one study [129], but not in another [120]; age probably is not related to psychological adjustment [116,117,120 and 129; but also see 128]. In sum, studies examining psychological reactions of CHD patients in the post-hospital period provide evidence of considerable anxiety and depression which persists months and sometimes years. However, it remains for future research to isolate specific social and psychological factors related to long-term maladjustment.

A handful of reports considered different aspects of the life style of the discharged patient. One paper reported that MI patients undergo more life changes within one year on either side of their illness [127] than 13 years after the illness. Another report found that many CHD patients evidence a sudden, sharp decrease in smoking and in body weight, with the former change, but not the latter, maintained for over 4 years [130]. On the other hand, one study [118] reported that their sample of Catholic. Protestant, and Jewish MI patients did not. in general. alter the extent of their religious beliefs or practices in the first year after the onset of their illness. Furthermore. these patients reported little change in contact with clergy [118] with most of their social support coming from family and friends [119]. Although former patients. in one investigation [130]. had a higher hospital utili- 
Table 5. A listing of research reports concerned with psychological and social factors in the post-hospital phase of recovery. The methodology and major findings are provided for each study

\begin{tabular}{|c|c|c|c|c|}
\hline $\begin{array}{l}\text { First author } \\
\text { (reference) }\end{array}$ & $\begin{array}{l}\text { Time since MI or } \\
\text { acute incident }\end{array}$ & Measures & Design & Findings and comments \\
\hline Brown $[115]$ & $1-8$ years & $\begin{array}{l}\text { Structured } \\
\text { interview and } \\
\text { psychological } \\
\text { test battery } \\
\text { including TAT } \\
\text { and I6 PF } \\
\text { inventory }\end{array}$ & $\begin{array}{l}\text { Studied } 41 \\
\text { MI patients }\end{array}$ & $\begin{array}{l}18 \text { patients had poor social adapta- } \\
\text { tion whereas } 23 \text { showed good quality } \\
\text { of life. No relationship between phys- } \\
\text { ical adjustment and psychological test } \\
\text { findings or patient's assessment }\end{array}$ \\
\hline Bruhn $[116,117]$ & $\begin{array}{l}2 \text { years. } \\
9 \text { years } \\
\text { and } 11 \text { years }\end{array}$ & $\begin{array}{l}\text { MMPI and } \\
\text { physiological } \\
\text { measures }\end{array}$ & $\begin{array}{l}38 \text { MI patients } \\
\text { compared with } \\
27 \text { healthy } \\
\text { controls }\end{array}$ & $\begin{array}{l}\text { Initially, patients significantly lower } \\
\text { on } \mathrm{K} \text { scale. At second testing controls } \\
\text { significantly lower on } \mathrm{F} \& \mathrm{~A} \text {, and higher } \\
\text { on } \mathrm{K} \& \mathrm{R} \text { scales. Over all the MMPI } \\
\text { testings. patients and controls did not } \\
\text { differ on Hs. D. Hy. or A: but only on } \\
\mathrm{K} \text {. During the course of the study. } \\
\text { there were no differences on Hs. D, Hy } \\
\text { for blue vs. white collar workers, nor } \\
\text { for patients on either side of } 50 \text {. White } \\
\text { collar workers had lower anxiety scores } \\
\text { than blue collar workers over the nine } \\
\text { year period. No differences on MMPI } \\
\text { between patients who did have short-term } \\
\text { therapy from those who did not. }\end{array}$ \\
\hline Croog $[118]$ & $\begin{array}{l}1 \text { month post- } \\
\text { discharge and } \\
1 \text { year post } \mathrm{MI}\end{array}$ & $\begin{array}{l}\text { Structured } \\
\text { interview about } \\
\text { religious atti- } \\
\text { tudes and } \\
\text { practices }\end{array}$ & $\begin{array}{l}324 \mathrm{MI} \\
\text { patients } \\
\text { followed for } \\
1 \text { year }\end{array}$ & $\begin{array}{l}\text { No significant changes, during the } \\
\text { first year after the MI, in: level } \\
\text { of religiosity, church attendance, } \\
\text { orientation to life and illness } \\
\text { experience. Little reported contact } \\
\text { with clergy. }\end{array}$ \\
\hline Croog [119] & $\begin{array}{l}1 \text { month post- } \\
\text { discharge and } \\
1 \text { year post } \mathbf{M I}\end{array}$ & $\begin{array}{l}\text { Structured } \\
\text { interview about } \\
\text { amount and type } \\
\text { of social } \\
\text { support received } \\
\text { from others }\end{array}$ & $\begin{array}{l}293 \mathrm{MI} \\
\text { patients } \\
\text { followed for } \\
1 \text { year }\end{array}$ & $\begin{array}{l}\text { Studied social support following an } \\
\text { MI. Kin group members, friends and } \\
\text { neighbors gave similar amounts of } \\
\text { reported over all assistance, with } \\
\text { non kin providing more services and } \\
\text { kin more financial help. Extent of } \\
\text { support was negatively related to age } \\
\text { of patient and unrelated to frequency } \\
\text { of prior visits. number of illness } \\
\text { setbacks. education, or social class. } \\
\text { There was minimal use of institutional } \\
\text { and professional services except for } \\
\text { that provided by the physician. }\end{array}$ \\
\hline Garrity [120] & 6 months & $\begin{array}{l}\text { Questionnaire } \\
\text { indices of } \\
\text { activeness. } \\
\text { social involve- } \\
\text { ment, morale. and } \\
\text { health measures }\end{array}$ & $\begin{array}{l}61 \mathrm{MI} \\
\text { patients were } \\
\text { studied }\end{array}$ & $\begin{array}{l}\text { None of the following was a predictor } \\
\text { of morale: activeness, social involve- } \\
\text { ment, age, socio-economic status, health } \\
\text { status. Best predictor was patient's } \\
\text { perception of his health. Data invali- } \\
\text { date notion that experience of a heart } \\
\text { attack is similar to the experience of } \\
\text { aging. }\end{array}$ \\
\hline Hahn [82] & 4-69 months & $\begin{array}{l}\text { MMPI, Eysenck's } \\
\text { MMQ and MPI }\end{array}$ & $\begin{array}{l}17 \text { CHD pat- } \\
\text { ients receiv- } \\
\text { ing group ther- } \\
\text { apy, vs } 16 \\
\text { patients not } \\
\text { in therapy }\end{array}$ & $\begin{array}{l}\text { No significant differences between } \\
\text { groups. Total sample more neurotic } \\
\text { than normal, i.e. for MMPI, higher } \\
\text { Hs, Hy and clinical scales; for } \\
\text { Eysenck. higher MPI score. }\end{array}$ \\
\hline Hellerstein [121] & $\begin{array}{l}\text { at least } 3 \text { months } \\
\text { and then } 6 \text { months } \\
\text { to } 2 \text { years later }\end{array}$ & MMPI & $\begin{array}{l}43 \text { coronary- } \\
\text { prone normals } \\
\text { compared to } \\
48 \mathrm{MI} \\
\text { patients }\end{array}$ & $\begin{array}{l}\text { Controls had significantly higher } \\
\text { scores on Ma scale at first testing } \\
\text { with no differences at follow up. } \\
\text { Total group was } 1 \text { S.D. } \\
\text { above normal mean on Hs, Hy and D. }\end{array}$ \\
\hline Hinohara $[122]$ & 2 years & $\begin{array}{l}\text { Interview, } \\
\text { subjective } \\
\text { judgement } \\
\text { about psycho- } \\
\text { logical reac- } \\
\text { tions }\end{array}$ & $\begin{array}{l}139 \text { CHD } \\
\text { patients } \\
\text { studied }\end{array}$ & $\begin{array}{l}20 \% \text { were retarded in reha- } \\
\text { bilitation because of judiged anxjety } \\
\text { states. }\end{array}$ \\
\hline Josten $[123]$ & not given & $\begin{array}{l}\text { Interview } \\
\text { ratings, } \\
\text { Eysenck's N \& E } \\
\text { scales, and } \\
\text { work resump- } \\
\text { tion data }\end{array}$ & $\begin{array}{l}\text { Results from } \\
97 \text { CHD patients } \\
\text { analyzed and } \\
\text { model fit to } \\
\text { data }\end{array}$ & $\begin{array}{l}\text { Model of three coping strategies } \\
\text { for dealing with emotional aspects } \\
\text { of rehabilitation and return to } \\
\text { work is proposed. }\end{array}$ \\
\hline Kavanagh [124] & $\begin{array}{l}6-8 \text { months, } \\
12-15 \text { months, } \\
\text { and } 16-18 \text { months }\end{array}$ & $\begin{array}{l}\text { Physiological } \\
\text { status measures } \\
\text { collected at } \\
\text { first two times, } \\
\text { MMPI at third }\end{array}$ & $\begin{array}{l}101 \\
\text { parients } \\
\text { studied }\end{array}$ & $\begin{array}{l}\text { Sample divided into three ad hoc } \\
\text { groups according to MMPI depression } \\
\text { score. No significant differences } \\
\text { between the three groups on any physio- } \\
\text { logical status measures collected either } \\
\text { prior to or following } 12 \text { month period of } \\
\text { endurance-type training. Most depressed } \\
\text { patients were significantly older and } \\
\text { significantly more likely to have high } \\
\text { systolic blood pressure than least } \\
\text { depressed group. }\end{array}$ \\
\hline
\end{tabular}


Table 5.-Continued

\begin{tabular}{|c|c|c|c|c|}
\hline $\begin{array}{l}\text { First author } \\
\text { (reference) }\end{array}$ & $\begin{array}{l}\text { Time since MI or } \\
\text { acute incident }\end{array}$ & Measures & Design & Findings and comments \\
\hline McGrath [125] & 6 months & $\begin{array}{l}\text { Interview. } \\
\text { subjective } \\
\text { judgement } \\
\text { about psycho- } \\
\text { logical and } \\
\text { social problems }\end{array}$ & $\begin{array}{l}70 \mathrm{CHD} \\
\text { patients } \\
\text { studied }\end{array}$ & $\begin{array}{l}\text { During o months alter MI. of "required } \\
\text { social work counseling for amotional. } \\
\text { marital and other life problems }\end{array}$ \\
\hline Mordkoff [126] & not given & $\begin{array}{l}\text { MMPI. WAIS } \\
\text { Clyde Mood } \\
\text { Scale }\end{array}$ & $\begin{array}{l}31 \text { CHD } \\
\text { patients } \\
\text { compared to } \\
31 \text { controls: } \\
\text { the } 31 \text { pairs } \\
\text { of subjects } \\
\text { were matched } \\
\text { on } 6 \text { vari- } \\
\text { ables }\end{array}$ & $\begin{array}{l}\text { Patient group split into } 3 \text { subgroups } \\
\text { on basis of extent of change in life } \\
\text { sicuation: marked reduction. moderate } \\
\text { reduction, or no change in activity. } \\
\text { Total patient group significantly } \\
\text { different from controls on F. K. Hs. } \\
\text { D. H. Si. K and Es. First two above } \\
\text { subgroups similar to each other on MMPI } \\
\text { and different from other Ss. Third } \\
\text { subgroup was very similar to controls. } \\
\text { Psychological tlexibility-rigidity not } \\
\text { related to form of adaptation. }\end{array}$ \\
\hline Rahe $[127]$ & $1-4$ years & $\begin{array}{l}\text { Schedule of } \\
\text { recent } \\
\text { experience }\end{array}$ & $\begin{array}{l}\text { Compared } \mathrm{LCL} \\
\text { totals within } \\
30 \mathrm{CHD} \\
\text { patients } \\
\text { as function of } \\
\text { time since } \mathrm{Ml}\end{array}$ & $\begin{array}{l}\text { Found build up in life change intensity } \\
\text { in year prior to MI and a gradual drop } \\
\text { in year following MI. Methodological } \\
\text { issues discussed }\end{array}$ \\
\hline Rodda $[128]$ & $5-6$ years & $\begin{array}{l}\text { MMPI sub- } \\
\text { scales: } \\
\text { Bendig Mani- } \\
\text { fest Anxiety } \\
\text { and Welsh } \\
\text { Depression }\end{array}$ & $\begin{array}{l}\text { 3) CHD patients } \\
\text { compared to } 46 \\
\text { normal controls } \\
\text { Markov analysis } \\
\text { performed on } \\
\text { two scale } \\
\text { scores for each } \\
\text { subject group } \\
\text { tested every } \\
6-8 \text { weeks for } \\
15 \text { months }\end{array}$ & $\begin{array}{l}\text { Patients were more anxious and more } \\
\text { depressed than controls. Anxiety } \\
\text { was age related: compared to controls. } \\
\text { patients under } 50 \text { were proportionately } \\
\text { more anxious than patients over } 50 \text {. }\end{array}$ \\
\hline Ruskin [129] & $\begin{array}{l}6 \text { months on } \\
\text { a verage; } \\
\text { follow up at } \\
19 \text { months }\end{array}$ & MMPI & $\begin{array}{l}\text { Compared } 128 \\
\text { CHD patients } \\
\text { with their } 128 \\
\text { spouses. } \\
\text { Patients all } \\
\text { had a vocation- } \\
\text { al problem }\end{array}$ & $\begin{array}{l}\text { Patients more than one standard devia- } \\
\text { tion above normal mean on } \mathrm{D} \text {. Hs. Hy. Pt: } \\
\text { spouses show greater adequacy than } \\
\text { patients, i.e. significantly different } \\
\text { on } 12 \text { scales, yet spouses are high on D } \\
\text { and hence somewhat depressed }\end{array}$ \\
\hline Wein blatt $[130]$ & $\begin{array}{l}6 \text { months. } \\
5 \text { years post } \\
\text { CHD onset }\end{array}$ & $\begin{array}{l}\text { Smoking habits. } \\
\text { weight change. } \\
\text { and hospital } \\
\text { utilization }\end{array}$ & $\begin{array}{l}\text { Three groups: } \\
470 \text { MI patients. } \\
275 \text { angina pat- } \\
\text { ients. } 2465 \text { non- } \\
\text { CHD controls: } \\
\text { all men. Com- } \\
\text { pared subsamples } \\
\text { on life styles } \\
\text { as function of } \\
\text { time since } \\
\text { acute CHD onset }\end{array}$ & $\begin{array}{l}\text { MI and angina groups did not differ } \\
\text { from each other on any measure. CHD } \\
\text { patients evidence a shatp. sudden drop } \\
\text { in smoking that persists for at least } \\
\text { four and one half years. A similar ini- } \\
\text { tial decrease in obesity of CHD patients } \\
\text { was not found at follow up. CHD patients } \\
\text { have a hospital utilization rate twice } \\
\text { that on non-CHD controls for the period } \\
6 \text { months to } 5 \text { years post onset. }\end{array}$ \\
\hline Wishnie $[131]$ & $4-10$ months & $\begin{array}{l}\text { Structured } \\
\text { interviews. } \\
\text { subjective } \\
\text { judgement of } \\
\text { psychological } \\
\text { factors }\end{array}$ & $\begin{array}{l}\text { Naturalistic } \\
\text { study of psycho- } \\
\text { logical hazards } \\
\text { of recovery of } \\
24 \text { MI patients }\end{array}$ & $\begin{array}{l}\text { Twenty one patients reported they were } \\
\text { anxious or depressed the first month at } \\
\text { home: for nine. feelings lasted months: } \\
\text { examiner judged is to require tranquil- } \\
\text { izers or antidepressants: suggestions } \\
\text { regarding treatment are offered }\end{array}$ \\
\hline Wynn [132] & $\begin{array}{l}\text { Post-hospital. } \\
\text { no more spec- } \\
\text { ific informa- } \\
\text { tion available }\end{array}$ & $\begin{array}{l}\text { Structured } \\
\text { interview } \\
\text { about } \\
\text { emotional } \\
\text { reactions }\end{array}$ & $\begin{array}{l}\text { Assessment of } \\
\text { unwarranted } \\
\text { emotional dis- } \\
\text { tress of } 400 \\
\text { CHD patients } \\
\text { using the sub- } \\
\text { jective } \\
\text { judgements of } \\
\text { the research } \\
\text { team }\end{array}$ & $\begin{array}{l}\text { Fifty percent of patients judged to have } \\
\text { unwarranted emotional distress and inval- } \\
\text { idism. mainly anxiety or depression. Chief } \\
\text { causes were lack of diagnosis and treat- } \\
\text { ment of nervous disorder: inadequate ex- } \\
\text { planation. no reassurance or rehabilita- } \\
\text { tion planning: patient's personality. } \\
\text { Fear induced in several ways-detailed } \\
\text { discussion of each is given. }\end{array}$ \\
\hline
\end{tabular}

Zation rate than healthy controls, another study [119] showed that their former patients did not use other. non-hospital, institutional or professional services. No investigation has considered the adequacy of the various social support services or life style changes in which the convalescing patient had participated. Given the high incidence of chronic emotional distress, as indicated above, the long-term effectiveness of such quasi-therapeutic measures must be brought into serious question.

Occupational adjustment. Table 6 contains informa- tion from investigations focusing upon occupational adjustment. Most of the papers [all but 143. 144, 148] dealt with return to work findings. The various reports generally provided data for nonequivalent age groups and for disparate time intervals. Comparisons between studies are also made difficult by the presence of uncontrolled variables which might reasonably be expected to influence employment. These include: variations in employability due to local economic conditions, regional or national differences in medical opinion regarding the optimal time for work 
Table 6. Summarized findings of research reports that deal with occupational adjustment of CHD patients

\begin{tabular}{|c|c|c|c|c|c|c|}
\hline $\begin{array}{l}\text { First author } \\
\text { (reference) }\end{array}$ & $\begin{array}{l}\text { No. of } \\
S^{3}\end{array}$ & Age & $\begin{array}{l}\text { Time since } \\
\text { acute episode }\end{array}$ & $\begin{array}{l}\text { yoturn } \\
\text { to work }\end{array}$ & $\begin{array}{l}\% \text { changed or } \\
\text { reduced work }\end{array}$ & $\begin{array}{l}\text { Variables examined for relation to } \\
\text { work return and/or additional data }\end{array}$ \\
\hline $\begin{array}{l}\text { Anderson }[134] \\
\text { (also Schiller } \\
\text { 135) }\end{array}$ & $\begin{array}{c}82 \\
\mid C H D\end{array}$ & $<65$ & about 6 months & 70 & $\mathrm{NR}^{4}$ & $\begin{array}{l}\text { Primary focus is description of rating } \\
\text { scale composed of weighted psycho- } \\
\text { social factors thought to be related } \\
\text { to work return. Scale needs further } \\
\text { empirical study }\end{array}$ \\
\hline Fisher [136] & $\begin{array}{l}124 \\
(\mathrm{Ml})\end{array}$ & $\begin{array}{c}<50 \\
5 j-65 \\
>66 \\
\text { all ages } \\
<6.5\end{array}$ & 1 year & $\begin{array}{l}95 \\
76 \\
56 \\
81 \\
83\end{array}$ & $\begin{array}{c}\text { NR } \\
\text { NR } \\
\text { NR } \\
7 \\
\text { NR }\end{array}$ & $\begin{array}{l}\text { Only young age was related to increasing } \\
\text { likelihood of work return. The following } \\
\text { were not related to work return: educa- } \\
\text { tion. history of angina or congestive } \\
\text { heart failure, functional class. recog- } \\
\text { nized or unrecognized MI. neurocircula- } \\
\text { tory asthenia. Included } S \text { s over } 65 \text {. } \\
\text { Advocates inclusion of psychological } \\
\text { factors in future studies }\end{array}$ \\
\hline Garrity [137] & $\begin{array}{c}58 \\
(\mathrm{MI})\end{array}$ & $37-74$ & $\begin{array}{l}2 \text { weeks. } \\
6 \text { months }\end{array}$ & 67 & NR & $\begin{array}{l}\text { Return to work related to: good percep- } \\
\text { tion of health status. high social class. } \\
\text { and sense of little control over late. } \\
\text { Return to work not related to: chronic } \\
\text { health problems, pre MI work load. clin- } \\
\text { ical severity of the attack, age. number } \\
\text { of dependents. propensity to take the } \\
\text { sick role. Amount of work return only } \\
\text { related to pre-MI work load and per- } \\
\text { ceived pressure from significant others. }\end{array}$ \\
\hline Groden [138] & $\begin{array}{l}55^{\prime} \\
(\mathrm{MI})\end{array}$ & $34-64$ & $\begin{array}{l}3 \text { months } \\
6 \text { months } \\
1 \text { year }\end{array}$ & $\begin{array}{l}44 \\
82 \\
84\end{array}$ & $\begin{array}{l}\text { NR } \\
\text { NR } \\
\text { NR }\end{array}$ & $\begin{array}{l}\text { Psychological factors and local econ- } \\
\text { omic conditions. but not medical status. } \\
\text { were judged most often to be responsible } \\
\text { for non-work return }\end{array}$ \\
\hline Hay [139] & $\begin{array}{l}269 \\
(\mathrm{MI})\end{array}$ & $<65$ & $\begin{array}{l}2 \text { months } \\
7 \text { months } \\
\text { and } \\
3.5 \text { years }\end{array}$ & $\begin{array}{l}67^{5} \\
88\end{array}$ & $\begin{array}{c}\text { NR } \\
45\end{array}$ & $\begin{array}{l}\text { Work return not related to: cardiac } \\
\text { symptoms. angina or complications dur- } \\
\text { ing acute illness. Opinion expressed } \\
\text { that psychological factors are impli- } \\
\text { cated in unsuccessful rehabilitation }\end{array}$ \\
\hline Hay [140] & $\begin{array}{c}171^{6} \\
(\mathrm{CHD})\end{array}$ & $\begin{array}{l}\text { Most } \\
46-70\end{array}$ & 4 months & 73 & NR & $\begin{array}{l}\text { Social-psychological data showed only } \\
\text { moderate emotional distress. Most } \\
\text { patients who delayed work return did } \\
\text { so on doctor's orders. Patient's doctor. } \\
\text { and not a treatment team. considered } \\
\text { most important determinant of quality } \\
\text { of recovery }\end{array}$ \\
\hline Higgins [141] & $\begin{array}{c}83 \\
(\mathrm{MI})\end{array}$ & $35-55$ & $\begin{array}{l}\text { variable. } \\
\text { no more } \\
\text { than } 18 \\
\text { months }\end{array}$ & 83 & NR & $\begin{array}{l}\text { Social factors. such as educational } \\
\text { level and occupational level, both } \\
\text { positively related to ease of work } \\
\text { return. Medical factors appeared less } \\
\text { important in effecting reemployment } \\
\text { although poorer functional status was } \\
\text { related to less return to work }\end{array}$ \\
\hline Hinohara [122] & $\begin{array}{c}119 \\
(\mathrm{M} 1)\end{array}$ & $\begin{array}{c}<65 \\
>65 \\
\text { all ages } \\
<65\end{array}$ & $\begin{array}{l}2 \text { years } \\
2 \text { years } \\
2 \text { years }\end{array}$ & $\begin{array}{l}93 \\
67 \\
83 \\
73\end{array}$ & NR & $\begin{array}{l}\text { In } 20 \% \text { of all patients, } \\
\text { delay in work return thought attrib- } \\
\text { utable to anxiety; contribution of } \\
\text { medical factors to work delay not } \\
\text { considered }\end{array}$ \\
\hline Kelierman [142] & $\begin{array}{l}256 \\
(\mathrm{MI})\end{array}$ & $\begin{array}{c}<40 \\
41-50 \\
51-64 \\
\text { all ages }\end{array}$ & $\begin{array}{l}\text { at least } \\
2 \text { years on } \\
\text { the average }\end{array}$ & $\begin{array}{l}63 \\
97 \\
89 \\
92\end{array}$ & $\begin{array}{r}37 \\
9 \\
12 \\
13\end{array}$ & $\begin{array}{l}\text { Eighty percent of patients returned } \\
\text { to work within } 5 \text { months. No consid- } \\
\text { eration given to possible reasons for } \\
\text { deiay in reemployment. Physical exer- } \\
\text { cise program during rehabilitation } \\
\text { advocated }\end{array}$ \\
\hline McGrath [125] & $\begin{array}{c}42 \\
(\mathrm{MI})\end{array}$ & all ages & 6 months & 86 & 33 & $\begin{array}{l}\text { Psycho-social counseling considered } \\
\text { important for successful occupational } \\
\text { adjustment }\end{array}$ \\
\hline $\begin{array}{l}\text { Monteiro } \\
{[143.144]}\end{array}$ & $\begin{array}{c}28^{7} \\
\text { (MI) } \\
358 \\
\text { (friend } \\
\text { of an } \\
\text { MI } \\
\text { patient) } \\
751^{-} \\
\text {(No } \\
\text { experience } \\
\text { with MI } \\
\text { patients) }\end{array}$ & $\begin{array}{l}\text { all ages } \\
\text { all ages }\end{array}$ & NR & NR & NR & $\begin{array}{l}\text { Survey about activity and work expec- } \\
\text { tations for rehabilitated MI patients. } \\
\text { Persons who knew an MI patient were most } \\
\text { favorable toward activity foltowed by } \\
\text { those with no experience with MI patients. } \\
\text { Group least favorable toward renewed } \\
\text { activity were former MI patients. } \\
\text { Education and income were positively cor- } \\
\text { related. age negatively correlated. and } \\
\text { sex unrelated to greater work and acti- } \\
\text { vity expectations }\end{array}$ \\
\hline Mulcahy [145] & $\begin{array}{c}18.3 \\
(\mathrm{CHD})\end{array}$ & $<60$ & $\begin{array}{l}14 \text { weeks } \\
\text { about } 4 \\
\text { years }\end{array}$ & $\begin{array}{l}75 \\
93\end{array}$ & NR & $\begin{array}{l}\text { Judged reasons for delay in work } \\
\text { return: social and economic }-39^{\circ} \text { : } \\
\text { medical }-27^{\prime \prime} \text {, : psychological- }-18^{\circ}, \\
\text { Comprehen sive rehabilitation program } \\
\text { described. }\end{array}$ \\
\hline Vagle $[146]$ & $\begin{array}{l}115 \\
(\mathrm{MI})\end{array}$ & $\begin{array}{c}56-65 \\
36-45 \\
\text { all ages }\end{array}$ & 4 months & $\begin{array}{l}45 \\
57 \\
50\end{array}$ & NR & $\begin{array}{l}\text { Positive relation between severity of } \\
\text { cardiac damage and non-return to work. } \\
\text { Of those with no sign of cardiac damage } \\
\text { who did not work. } 47 \% \text { admitted anxiety } \\
\text { and depression. }\end{array}$ \\
\hline
\end{tabular}


Table 6.-Continued

\begin{tabular}{|c|c|c|c|c|c|c|}
\hline $\begin{array}{l}\text { First author } \\
\text { (reference) }\end{array}$ & $\underset{\mathrm{Ss}^{1}}{\mathrm{No} \text { of }}$ & Age & $\begin{array}{l}\text { Time since } \\
\text { acute episode }\end{array}$ & $\begin{array}{l}\because \text { return } \\
\text { to work }\end{array}$ & $\begin{array}{l}\text {. changed or } \\
\text { reduced work }\end{array}$ & $\begin{array}{l}\text { Variables examined for relation to } \\
\text { work return and or additional data }\end{array}$ \\
\hline \multirow[t]{4}{*}{ Shapiro [147] } & $\begin{array}{c}540 \\
(\mathrm{MI})\end{array}$ & $25-64$ & 6 months & 82 & $\begin{array}{l}1 \text { year post- } \\
\mathrm{MI} \text { : }\end{array}$ & \multirow{4}{*}{$\begin{array}{l}\text { Older age. lower occupational level. } \\
\text { and greater clinical severity of acute } \\
\text { episode reduce rate and proportions } \\
\text { returning to work: hypertension not } \\
\text { a factor. Under } 55 \text {. blue collar men } \\
\text { more likely to change jobs than white } \\
\text { collar men. Over } 55 \text {. blue collar men } \\
\text { more likely to retire than white collar } \\
\text { men. }\end{array}$} \\
\hline & $\begin{array}{l}470 \\
(\mathrm{MI})\end{array}$ & $25-64$ & 1 year & 92 & $\begin{array}{c}11 \text { (white } \\
\text { collar) } \\
37 \text { (blue } \\
\text { collar) }\end{array}$ & \\
\hline & & & & & & \\
\hline & $\begin{array}{c}783 \\
\text { (non-CHD) }\end{array}$ & $25-64$ & 5 years & 83 & & \\
\hline Thockloth [79] & $\begin{array}{c}100 \\
(\mathrm{MI})\end{array}$ & $21-60$ & 4 months & 67 & NR & \multirow[b]{2}{*}{$\begin{array}{l}\text { Additional findings are discussed above } \\
\text { within the clinical papers section. } \\
\text { Questionnaire about the hiring of persons } \\
\text { with various conditions. e.g. previous } \\
\text { MI. angina. hypertension. diabetes. pre- } \\
\text { vious psychiatric illness. Over atl con- } \\
\text { ditions. a former employee is more than } \\
\text { twice as likely to be rehired compared } \\
\text { to a new employee being hired. For all } \\
\text { conditions except a previous psychiatric } \\
\text { illness. a person would have a better } \\
\text { chance obtaining a managerial or clerical } \\
\text { position than a maintenance position. } \\
\text { For a previous MI. about } 60^{\circ} \text { of the } \\
\text { physicians would hire an asymptomatic } \\
\text { new employee but less than } 30^{\circ} \% \text { would } \\
\text { hire a new employee with symptoms. } \\
\text { Corresponding percentages for former } \\
\text { employees are about } 30^{\circ} \% \text { higher. }\end{array}$} \\
\hline $\begin{array}{l}\text { Weinstock } \\
{[148]}\end{array}$ & $\begin{array}{c}45 \\
\text { (Industrial } \\
\text { physicians) }\end{array}$ & NR & NR & NR & NR & \\
\hline
\end{tabular}

\footnotetext{
coronary incident; men who retired only after MI were considered employed.

${ }^{3}$ Per cent of all persons who were working at the indicated time.

${ }^{4} \mathrm{NR}=$ data not reported

${ }^{5}$ Figure inflated since patients who retired post discharge were excluded from calculation.

${ }^{6} 26 \%$ were females.

$751 \%$ of total sample were females.
}

${ }^{1}$ Medical diagnosis given in parenthesis. CHD indicates that other than MI patients were included, e.g. acute myocardial ischemia, acute coronary insufficiency. Where possible, the subgroups were separated on the table. Unless noted, patients were males. Studies which contained some patients with prior history of CHD were [138, 140 and 147].

${ }_{2}^{2}$ Per cent employed, full or part-time, of all persons living at the indicated time who were employed prior to their

return, study of patient cohorts with different socioeconomic characteristics, inclusion of patients with different medical diagnoses and histories, enrollment in rehabilitation programs with varying emphases and intensities. Thus, only variables that were altered systematically within studies will be considered.

Younger age was associated with a greater rate and proportion returning to work $[122,136,146,147$, but not 137]. This relationship may be partly due to the greater possibility of retirement for older men and the easier chance of younger men finding, when necessary, different employment. Poorer functional status had a deleterious effect upon work return for patients in some reports $[129,141,146,147]$ but not in others $[136,137,139]$. A number of studies found that educational and occupational factors are related to work return--the better educated, white collar worker more easily returns to, and adapts to, reemployment than the less educated blue-collar worker, who is more likely to return more slowly, change jobs or retire $[116,117,137,141,145,147,148]$. Likewise, psychological factors were implicated in delay of work return $[122,125,134,137,138,141,146]$ and in some studies, were judged to be much more important than medical factors $[138,139,141]$. These conclusions are in substantial agreement with those reached by Garrity [137] in a review of some of the same literature.
The refinement of a rating scale $[134,135]$ for identifying patients likely to have problems with work return would be most helpful. It might prove useful to include an assessment of the patient's attitude toward work $[143,144]$ as another predictor of occupational adjustment, along with those mentioned above.

In order to obtain a global estimate of the extent of reemployment of CHD patients, further calculations were performed upon the data in Table 6 . The resulting information applies to the collection of heterogeneous, perhaps unrepresentative, subject samples in the various studies and is not indicative of patients with any set of demographic or social or psychological characteristics. For surviving patients previously employed, roughly $75 \%$ return to some type and amount of work within 6 months of the acute incident, with about $85 \%$ returning by 12 months.

Using return to work as the outcome measure, it appears that CHD does not bring about long-lasting disruptions in occupational adjustment. Yet there are other aspects of work return that merit consideration. Aside from clinical impressions [e.g. 75] about difficulties in adjusting to work, there is scant empirical information. Table 6 does indicate that perhaps $20^{\circ}{ }^{\circ}$ of all work returners either change jobs or reduce their hours $[125,136-139,142,147]$. It has been well documented that similar alterations in the employ- 
Table 7. Salient information of published reports dealing with mortality as a function of demographic, social and psychological variables

\begin{tabular}{|c|c|c|c|}
\hline $\begin{array}{l}\text { First author } \\
\text { (reference) }\end{array}$ & Study population & Research design & Summary of findings \\
\hline Bartle $[150]$ & $\begin{array}{l}18 \text { CHD patients with } \\
\text { unexpectedly long } \\
\text { survival, } 10 \text { years }\end{array}$ & $\begin{array}{l}\text { MMPI scores } 10 \text { years after } \\
\text { MI as compared with other } \\
\text { patient groups }\end{array}$ & $\begin{array}{l}\text { Patients had normal scores. } \\
\text { whereas comparison patient } \\
\text { groups had significantly } \\
\text { deviant scores }\end{array}$ \\
\hline Bruhn [116] & $\begin{array}{l}17 \text { fatalities and } \\
30 \text { survivors } 7 \text { years } \\
\text { post Ml who were part } \\
\text { of a longitudinal } \\
\text { study }\end{array}$ & $\begin{array}{l}\text { MMPI scores } 20 \text { munths after } \\
\text { MI for fatalities and } \\
\text { survivors } 5.5 \text { years layer }\end{array}$ & $\begin{array}{l}\text { Falalities had significantly } \\
\text { higher score on } D \text { (depression) } \\
\text { scale than survivors. } \\
\text { No other differences. }\end{array}$ \\
\hline Croog $[151]$ & $\begin{array}{l}309 \text { first MI patients. } \\
\text { under } 60 \text {, with no } \\
\text { previous major illness } \\
\text { nor major medical com- } \\
\text { plications within } 3 \\
\text { weeks post MI }\end{array}$ & $\begin{array}{l}\text { Mortality and morbidity in } \\
\text { one year as function of age, } \\
\text { social status. ethnic origin. } \\
\text { religion. personality self- } \\
\text { rating and marital status }\end{array}$ & $\begin{array}{l}\text { None of the variables were } \\
\text { related significantly io either } \\
\text { mortality or morbidity }\end{array}$ \\
\hline Geismar [152] & $\begin{array}{l}\text { All cases of acute } \\
\text { Ml discharged from } \\
\text { hospitals in Denmark } \\
\text { from } 3 / 63 \text { to } 4 / 63 \text {. } \\
N=642\end{array}$ & $\begin{array}{l}\text { Yearly survival rate for } \\
\text { first } 8 \text { years as function of } \\
\text { age, sex, follow-up year and } \\
\text { number of previous Mls }\end{array}$ & $\begin{array}{l}\text { No sex difference in mortality } \\
\text { rate; absolute mortality increased } \\
\text { with age and recurrent MI(s), and } \\
\text { declined with follow-up year }\end{array}$ \\
\hline Hrubec [153] & $\begin{array}{l}1495 \text { white males } \\
\text { alive } 6 \text { months after } \\
\text { admission to hospital } \\
\text { with CHD between } 6 / 43 \\
\text { and } 12 / 44 \text {. All werc } \\
\text { members of the U.S. } \\
\text { Army }\end{array}$ & $\begin{array}{l}\text { Survival rate after } 18 \text { years } \\
\text { as function of education. } \\
\text { occupation, marital status }\end{array}$ & $\begin{array}{l}\text { Physicians and surgeons have } \\
\text { higher survival rate than other } \\
\text { professionals who, in turn, have } \\
\text { slightly better prognosis than non- } \\
\text { prolessionals, irrespective of } \\
\text { diagnosis. Married men had more } \\
\text { favorable prognosis than single. } \\
\text { divorced, separated or widowed men }\end{array}$ \\
\hline Shapiro $[154]$ & $\begin{array}{l}882 \text { first MI male } \\
\text { patients followed to } \\
4 \text { years post infarct } \\
\text { who were part of a } \\
\text { large insurance } \\
\text { group in NY state }\end{array}$ & $\begin{array}{l}\text { Survival rate at } 48 \text { hours, } \\
1 \text { month, } 6 \text { months, } 4 \text { years } \\
\text { post } \mathrm{MI} \text { as function of age, } \\
\text { color, education, religion, } \\
\text { occupation and blood pressure }\end{array}$ & $\begin{array}{l}\text { Higher mortality ratc with increased } \\
\text { age declines somewhat with time } \\
\text { since MI, small number of nonwhite in } \\
\text { sample show poorer prognosis through- } \\
\text { out } 4 \text { years, college and Jewish men } \\
\text { have slightly lower mortality than } \\
\text { non-college and non-Jewish men; the } \\
\text { greater mortality of blue collar } \\
\text { men compared to white collar men is } \\
\text { only for those with elevated blood } \\
\text { pressure }\end{array}$ \\
\hline $\begin{array}{l}\text { Weinblatt [155] } \\
\text { (see also } \\
\text { Frank. 156) }\end{array}$ & $\begin{array}{l}881 \text { men with first } \\
\text { MI: predominantly } \\
\text { white, married, } \\
\text { employed at time of } \\
\text { MI: half white collar, } \\
\text { half blue collar; all } \\
\text { enrolled in an insur- } \\
\text { ance group in NY state }\end{array}$ & $\begin{array}{l}\text { Mortality and recurrence } 1 \\
\text { month and } 4.5 \text { years foll- } \\
\text { owing first } \mathrm{MI} \text { as a function } \\
\text { of age, prior CHD, smoking; } \\
\text { all at time of } \mathrm{MI}\end{array}$ & $\begin{array}{l}\text { Mortality within } 1 \text { month related to } \\
\text { older age, and not related to prior } \\
\text { smoking habits. Higher mortality } \\
\text { and recurrence rates over next } 4.4 \\
\text { years for those who survived at } \\
\text { least } 1 \text { month, was also related to } \\
\text { age but not prior smoking habits. } \\
\text { Risk of reoccurence and death } \\
\text { declines with time since the } \mathrm{MI} \text {. } \\
\text { For all patients, first } 24 \mathrm{hr} \\
\text { after onset of clinical symptoms } \\
\text { is period of highest mortality }\end{array}$ \\
\hline Woodhouse [157] & $\begin{array}{l}320 \text { patients with MI, } \\
\text { coronary insufficiency } \\
\text { or myocardial ischemia } \\
\text { discharged from } 2 \text { Aus- } \\
\text { tralian hospitals }\end{array}$ & $\begin{array}{l}\text { Yearly survival rate } \\
\text { for } 5 \text { years as function of } \\
\text { age and sex }\end{array}$ & $\begin{array}{l}\text { Men }<70 \text { at time of incident have } \\
\text { a higher survival rate than men } \\
>70 \text {. Comparison between men and } \\
\text { women not possibie since data are } \\
\text { not equated on age for both group- } \\
\text { ings. }\end{array}$ \\
\hline
\end{tabular}

ment of healthy persons can provoke distress [149]. Given the high incidence of post-hospital emotional distress discussed earlier, it follows that some work returners must be within the sub-sample of patients with long-lasting psychological problems. As Croog et al. [2] argued, the fact that most CHD patients return to work does not, in itself, demonstrate that work has a positive therapeutic effect. In conclusion, even though return to work figures are objective and easily obtainable, other more complicated and sophisticated empirical approaches should be undertaken in order to understand more fully the course of occupational adjustment for the convalescing CHD patient.

Mortality. The final category of papers focusing upon the post-hospital period following acute CHD deals with an issue that is in the thoughts
$[66,67,70,75]$ of every patient-mortality, or its converse. longevity. Prognosis after acute $C H D$ has been studied as a function of psychological, social-demographic, dietary, and physiological variables. The research data of mortality studies dealing with socialpsychological findings (see Table 7) will be reviewed here. For mortality as a function of dietary and physiological variables, see [158-166].

An examination of Table 7 indicates that the study populations and research designs of the investigations varied greatly. Hence, disagreements about the relationship between a particular variable and mortality may be related to methodological differences between conflicting studies and not to the questionable impact of the variable at issue.

The rate of mortality, in general, was positively related to age at the time of the MI 
[152.154.155, 157. but not 151], declined with time since the MI [152,154 and 155] and increased with recurrent MIs (152). The one study which reported on the variable found no sex differences in mortality rate [152]. Another [155] reported that prior smoking did not affect mortality over a period of 4.4 years post-MI.

The mortality findings with regard to social factors suggested that more education [153,154, but not $151]$, higher occupational level $[153,154$, but not 151], and perhaps religion [154, but not 151], might provide a patient with a more favorable prognosis. Likewise, one study [153] found that married men had a more favorable prognosis than single, divorced, separated, or widowed men.

Two papers [116 and 150] reported the relationship between MMPI scores and mortality, Long-term survivors had relatively normal MMPI scores about 10 years after the incident [150]. In a second study, later fatalities were more depressed than survivors [116].

Presumably, reduced mortality as a function of younger age, increased time since the incident, and fewer occurrences may be explained by theories of physiological functioning. It is more problematic to account for the relationships between social and psychological factors and reduced mortality, assuming further research with more sophisticated designs corroborate the preliminary findings noted above. Future investigation could determine if, for example, social and psychological factors are related to styles of eating, relaxing, and working that, in turn, reduce the occurrences of mortality from CHD (for a thorough discussion of this issue. see [167]). Likewise, the direction of causality between a psychological state and mortality needs to be specified. The depressed patient may die sooner, not because depression causes death, but because the more gravely at-risk patient becomes depressed as a result of his declining physical condition.

In concluding the discussion of the post-hospital phase following acute CHD, mortality data contained in five papers $[152,155,157,162,166]$ will be mentioned. Variability in the reported findings on survival rates could be due to sample differences in factors such as age. occupation, education, prior acute episode(s) and/or angina, medical diagnosis and complications. In addition, regional or national differences in medical care regarding the hospitalization of mild cases [152] or in the nonavailability of CCUs [157] might have affected mortality of the different patient groups. For these reasons, the survival of a patient sample, or any patient, cannot be determined using the information which follows. The first $24 \mathrm{hr}$ after the onset of acute symptoms is probably the period of highest mortality $[155,166]$. In a representative [155] American middle class sample, $36.0 \%$ of first MI patients under 65 years died within 1 month, with $85.5 \%$ of these dying within the first day. Four studies collected mortality data for at least 4 years following the acute incident $[152,155,157,162]$. The percentages of patients who had their first MI within a given age range, survived it by at least 1 month, and were still alive for a specified time period are: $62.0 \%$ of all ages for 4 years [152]. $86.5 \%$ of persons under 60 for 4 years [162], $81.4 \%$ of persons under 65 for 4.5 years $[155], 71.9^{\circ}$ of persons under 70 for 4 years
[157]. and 27.5" of persons over 70 for + rears [157].

Before turning to a general discussion of the research reports one substantive issue remains: the relationship between physiological factors and psychological factors. The several different aspects of this relationship will be considered in turn.

A number of studies have considered the corre. spondence between physiological functioning and psychological affect states $[71.81 .94,98,99,104.110]$ of hospitalized patients. The data reported by Parker and Hodge [98] suggested a positive trend between severe myocardial damage and delirium. In two separate studies. Leigh et al. [99] and Gruen [81] found a relationship between extreme feeling states. e.g. anxiety, and the development of arrhythmias in the CCU. Klein et al. [71] and Bruhn et al. [94] demonstrated that psychological stress can bring about cardiovascular complications. On the other hand, Miller and Rosenfeld [104] and Froese et al. [110] observed few correlations between physiological measures and ratings of feelings. In general, there appears to be a positive association between physiological functioning and psychological functioning when both factors are assessed on hospitalized patients during a relatively narrow time span.

Another area of empirical interest is the correspondence between general long-term psycho-social status and physiological functioning. Cay et al. [101] reported that psycho-social level was not related to the severity of the heart attack. Over one-half of Wynn's [132] patients were judged to be suffering emotional distress in excess to that due to the consequences of the physical illness. Also, as it has already been noted, the relation between functional status and reemployment is not a direct one psychological factors can play a larger role than physiological factors in determining occupational adjustment. In conclusion, the literature indicates that the relationship between physiological functioning and general. longterm psycho-social adjustment is far from perfect; i.e. knowledge about one area of a person's functioning does not. in general. make it possible to predict the extent of functioning in the other area.

Another issue involves the relevance of psychological factors to physical mobilization and exercise training. In two related papers $[168,169]$ Groden et al. found no lasting psychological effects of early mobilization as compared to late mobilization. Likewise, Naughton et al. [170] found no differences on the MMPI between two MI patient groups, one of which underwent an extensive reconditioning program and the other of which remained sedentary. Similarly, Kavanagh et al. [171] found no differences in physiological functioning between an MI patient group who completed a 1-year physical exercise program and another group of MI patients who participated in a hypnotherapy group. Kavanagh et al. [124] found no differences in physiological functioning between a group of very depressed MI patients, according to the MMPI, and a group of MI patients without depression. Although the studies just cited suggest no psychological effect of exercise training and no physiological effect of emotional distress. the opposite sentiments are generally expressed in the literature $[20,23,172,173]$. These discrepancies can only be clarified by adequate empirical study. 
Sexual activity following an Ml also involves psychological and physiological factors. For a discussion of the physiological functioning of CHD patients during sexual intercourse see Green [5] and Hellerstein and Friedman [121]. As mentioned above. patients report being uneasy, if not unable, to reestablish normal sexual relations during recovery $[67,73]$. Two additional investigations $[121,174]$ administered questionnaires about sexual activity to recovering MI patients. One study found a $48 \%$ decline in activity post MI [174], and the other a $24 \%$ drop [121]. Reasons given for diminished activity were, in order, decrease in desire, depression, anxiety, wife's decision, fear of relapse or death, fatigue, angina, and impotence [174]; decrease in desire, wife's decision, depression, fears, symptoms of CHD [121]. The infrequent mention of impotence in either study contrasts with other reports [e.g. 67,73] and may be due to differences in the methods used to collect the data. In conclusion, it appears that changes in the sexual activity of MI patients are more often reported to be due to psychological factors than to physiological factors.

Empirical investigations of social-psychological aspects of recovery following CHD have exclusively studied patients after, and never before, the acute incident. Therefore, the separate effects of and interactions between the patient's premorbid personality and stress reactions brought on by the catastrophic illness [27] have not been systematically and scientifically examined. Many of the articles cited in Table 1 have dealt with this problem by assuming that all CHD patients have coronary-prone personalities [4] and have hypothesized emotional reactions, and recommended treatment accordingly. (Croog et al. [2] also cited this phenomenon in their earlier review.) Some recent papers have begun to examine this very important issue empirically [see 175,176$]$. But, in large part, the research reports mentioned above did not assess the premorbid personality and implicitly ascribed the post $C H D$ reactions to the illness itself.

Another solution to the issue has been used in studies [e.g. 177-180] collecting psycho-social data from $\mathrm{CHD}$ patients after the acute episode and then inferring the personality and/or behavior of the person prior to the incident. Moreover, a couple of these papers went on to conclude that the inferred pre-CHD personality traits brought about the CHD episode. The authors of the articles acknowledged the tenuousness of their reasoning but were willing to speculate on possible premorbid indicators and determinants of acutc cpisodes. Zohman [29] and Bruhn [181] point out that the illness itself may affect the personality and behavior of the person. Of course, the major practical difficulty is that there is no easy way to identify and examine CHD patients, prior to acute onset. on variables thought to be related to incidence and recovery. Nevertheless, either more legitimate methodological procedures should be developed or prospective studies undertaken.

Another procedure of data analysis and interpretation with some questionable aspects has been used in a number of studies [e.g. $134,135,161.163,164,182]$. The goal was to isolate a set of variables. assessed shortly after the acute incident. which were related to short-term and/or longterm adjustment such that appropriate rehabilitative measures could hopefully be administered to high-risk patients. Data were generally collected on a large number of variables from a large group of patients. Then, the sample was split into, for example, fatalities and survivors and the variables weighted so as to maximize the differentiation of the two groups. The variables which sharply divided the groups were assumed to reflect characteristics which brought about the outcome. The methodological shortcoming is the lack of replication on other groups of patients or a test of the discriminate formula in a predictive study. Without a replication there is no way to determine if the findings are specific to the original sample and without predictive validity.

Except for the above critical comments, it must be pointed out that the quality and quantity of empirical work on the psycho-social recovery of acute CHD patients have improved and increased considerably since the Croog et al. [2] review. More sophisticated designs and analyses have generated much data about the many conceptual issues within the field. Future research, especially that testing theories [2] of psychosocial rehabilitation, will advance the state of knowledge and range of application even further.

\section{CONCLUSIONS}

The majority of papers reviewed above studied acute CHD patients after the first episode of the illness, who lived in English-speaking countries (i.e. the United States, Great Britain, or Australia) often near large metropolitan hospitals with emergency services. Hence, the following conclusions, based on the above review of the literature, are most applicable to populations similar to the samples studied.

(1) About one-half of patients with relatively easy access to a hospital emergency service reach the hospital at least 3 hours after the onset of recognized acute symptoms. This is prima facie evidence of the involvement of psychological or social factors. However, empirical studies have not isolated specific psychological or social factors responsible for the delay. A crucial finding reported by five studies is that previous MI patients do not arrive sooner than those with no history of an MI.

(2) There is no good evidence that CCU procedures and events, such as attachment to a cardiac monitor or witnessing the cardiac arrest of another patient, cause short-term or long-lasting emotional disturbance in the typical CCU patient. Additional sophisticated research would be heipful here.

(3) Several research papers reporting on patients in American hospitals suggest that the typical patient with acute CHD is quite anxious for a couple of days following the acute incident but does not generally become depressed during the first two weeks. The role of the defense mechanism of denial in facilitating or deterring recovery is not clearcut. The suggestion that social factors. e.g. SES level, might be related to reassurance by medical personnel and the hospital environment and to expectations about the future, needs further study.

(4) The emotional distress of most CHD patients reaches a peak after hospital discharge during conva- 
lescence at home. Some patients become very depressed at this time. Family tensions are common. Nonetheless, one study suggested that patients seek and receive most of their social support from relatives, friends and their doctor and very little from institutional or professional services.

(5) Although the vast majority, roughly $85 \%$, of patients are found to be reemployed one year after the acute incident, many, perhaps $25 \%$, still report anxiety and depression. Poor occupational adjustment, as evidenced by delayed return to work or no return to work, probably is seen more often with blue-collar workers, less educated people, patients with lasting emotional distress, or patients with serious medical problems. Further study is needed here.

(6) The data from two papers suggest that most patients do not return to their previous leveis of sexual activity because of reported psychological and interpersonal concerns, rather than due to a physical consequence of the illness.

(7) Additional research is needed to relate mortality rate with social and psychological factors. Some data suggest that SES level and a stable marital status are related to a good prognosis.

(8) The interrelationship between psychological states and exercise training requires further study. The positive association between physiological functioning and psychological functioning found in a handful of articles studying hospitalized patients is not seen when long-term rehabilitation is considered. Adjustment in one area does not, in many cases, predict to adjustment in the other area.

(9) Many psychological and social counseling programs probably reduce the emotional distress to patient and family that is caused by acute CHD. But, additional scientific research is needed to determine the type and extent of counseling that is most effective for different types of patients.

\section{RECOMMENDATIONS}

Several issues, not mentioned above, are important in assessing the current state of knowledge in the field and in suggesting future directions. Some have been discussed by commissions, task forces, conferences. knowledgeable researchers and reviewers [183-191].

(1) It has not been demonstrated that coronary rehabilitation programs, whatever their nature, reduce mortality [187]. Other justifications, e.g. improving the quality of remaining years, must be advanced for such programs. Furthermore, the lack of perfect correspondence between physiological functioning and psychological functioning implies that a rehabilitation program which improves the physiological (psychological) status of CHD patients will not necessarily add to their emotional (physical) well-being.

(2) Large international studies of cardiac rehabilitation have often been advocated $[187,189,190]$ with the rationale that world-wide sharing of information will be beneficial to all. A note of caution: living conditions, diet, social structure, occupational environment, and so on, probably vary from one country to the next so much that only very broad conclusions could be generalized. It would be more worthwhile to coordinate more research programs, each on a smaller scale, collating data from fewer countries, so as to make more specific and more substantive recommendations.

(3) It has often been advocated that the patient's physician is and should be the primary care-giver $[131,183,185,186]$. Further, that social and psychological counseling can be handled easily by the physician [183]. Although these are empirical issues [185], it is disturbing that opinions are often made without reference to scientific evidence, as if such evidence is not relevant. Yet, research might show, for example, that physicians do not have the training or inclination to counsel their patients about psychological problems. Factors such as professional territorial boundaries must be considered in implementing policies but should not be predominant over scientific evidence in determining policies. It is ironic that many authors advocating large-scale psycho-social counseling programs for CHD patients by non-physicians are just as oblivious to the need for sound data.

(4) The fact that many different kinds of professionals are making contributions to the field has a number of implications. As already noted, there are different standards of proof ranging from careful scientific reasoning to deeply held impressions. Some work is done to help patients, other work to make a theoretical contribution. Compared to other areas of investigation, there is relatively little awareness of the ongoing studies of other people in the field. These factors tend to impair coordinated progress. Hopefully, the presence of such diversity will have a benefcial effect in the long run.

(5) Throughout this review, comments were often made about the necessity for further research on a given issue. One area deserving emphasis concerns the psycho-social effects of acute CHD upon family members [184]. Several papers have focused upon spouses of patients but very few have examined the effects upon and reactions of the children of patients. Yet, these children are likely to be the next generation of CHD patients and thereby merit special attention.

(6) One view of the state of knowledge about psycho-social aspects of cardiac rehabilitation is that it is well-advanced and that information-dissemination to clinical practice is the next step [191]. This is an overly optimistic assessment. We are now closer to the stage of initiating large-scale clinical research studies of theories of psycho-social rehabilitation. Such investigations should be designed not only to prolong the life of the CHD patient but also to enhance the quality of life among sufferers of a disease that characteristically has profound psychological and social consequences.

Acknowledgements-I wish to thank Dr. Ralph W. Heine and Dr. Margery J. Doehrman for their helpful comments and support, and Dr. Frederick Wyatt for his encouragement of my interest in this area. The literature search was facilitated by the use of Medline Search at the National Library of Medicine.

\section{REFERENCES}

1. Lancet editorial 2. 591, 1971.

2. Croog S. H.. Levine S. and Lurie $Z$. The heart patient and the recovery process: a review of the literature on social and psychological factors. Soc. Sci. Med 2. 111, 1968. 
3. Fisher S. Psychological aspects of cardiac rehabilitation. Acta cardiol. (Suppl.) XIV. 1969.

4. Jenkins C. D. Recent evidence supporting psychologic and social risk factors for coronary disease. N. Engl. J. Med. 294. 987, 1033, 1976.

5. Green A. W. Sexual activity and the postmyocardial infarction patient. Am. Heart J. 89. 246, 1975.

6. Burch G. E. and Giles T. Aspects of the influence of psychic stress on angina pectoris. Am. J. Card. 31. $108,1973$.

7. Ishikawa H., Tawara L., Ohtsuka H. et al. Psychosomatic study of angina pectoris. Psychosomatics 12. $390,1971$.

8. Mayou $R$. The patient with angina: symptoms and disability. Postgrad. Med. 49. 250, 1973.

9. Abram H. S., Hollender M. H., Horton F. T. et al. Clinical conference: coronary artery bypass operation-psychological and medical problems. J. Tenn. St. Med. Ass. 66. 828. 1973.

10. Dlin B. M.. Fishcer H. K. and Huddell B. Psychologic adaptation to pacemaker and open heart surgery. Archs gen. Psychiat. 19. 599, 1968.

11. Dlin B. M., Stern A. and Poliakoff S. J. Survivors of cardiac arrest. Psychosomatics 15. 61, 1974.

12. Greene W. A.. Goldstein S. and Moss A. J. Psychosocial aspects of sudden death. Archs intern. Med. 129. $725,1973$.

13. Kavanagh T. and Shephard R. J. Importance of physical activity in post-coronary rehabilitation. $\mathrm{Am}$. J. phys. Med. 52. 304, 1973.

14. Abraham A. S., Sever Y., Weinstein M. et al. Value of early ambulation in patients with and without complications after acute myocardial infarction. $N$. Engl. J. Med. 292. 719, 1975.

15. Cohen B. S. A program for rehabilitation after acute myocardial infarction. Sth. med. J. 68. 145, 1975.

16. DeBacker D., Depoorter A. M., Willems P. et al. The influence of rehabilitation on the physical performance aftermyocardial infarction - a controlled trial. Acta cardiol. 29. 427, 1974.

17. DeBusk R. F., Spivack A. P., van Kessel A. et al. The coronary care unit activities program: its role in postinfarction rehabilitation. J. chron. Dis. 24, 373. 1971.

18. Harpur J. E., Kellett R. J., Conner W. T. et al. Controlled trial of early mobilization and discharge from hospital in uncomplicated myocardial infarction. Lancet 2. $1331,1971$.

19. Kavanagh T., Shephard R. J. and Poney H. Hypnosis and exercise- a possible combined therapy following myocardial infarction. Am. J. clin. Hyp. 16. 160, 1974.

20. Kellerman J. J. Rehabilitation of patients with coronary heart disease. Prog. cardiovasc. Dis. 17. 303, 1975.

21. Morgans C. M. and Buston W. M. Supervised circuit training after myocardial infarction. Physiotherapy $\mathbf{5 8 .}$ $340,1972$.

22. Murray A. Cardiac survival and rehabilitation. Physiotherapy 59. 383, 1973.

23. Nye E. R, and Poulsen W. T. An activity programme for coronary patients: a review of morbidity, mortality and adherence after five years. N. Z. med. J. 79. 1010. 1974.

24. Rigner K. G. and Wilhelmsson S. Physical exercise and rehabilitation after myocardial infarction. Scand. J. rehabil. Med. 2. 13, 1970.

25. Shah C. V. and Manerikar A. S. Short and simple programme of cardiac rchabilitation following acute myocardial infarction. Indian heart J. 26. 301, 1974.

26. Hackett T. P.. Froese A. P. and Vasquez E. Psychological management of the CCU patient. Psychiatry in Medicine 4. 89. 1973.

27. Miller M. G. and Brewer J. Factors influencing the rehabilitation of the patient with ischemic heart disease. Med. J. Aust. 4. 410, 1969.
28. Naughton J. and Bruhn J. Emotional stress, physical stress and ischemic heart disease. DM, Disease-aMonth. July, 1970.

29. Zohman B. L. Emotional factors in coronary disease. Geriatrics 28. 110, 1973.

30. Anderson D. E. Rehabilitation programme for coronary patients. Singapore med. J. 14. 370, 1973.

31. Askanas K., Zera E. and Ruzyllo E. Results of sanatorium rehabiltation of patients with recent myocardial infarction. Materia Medicus, Poland 547 , 1973.

32. Baden C. A. Teaching the coronary patient and his family. Nurs. Clin. N. Am. 7. 563, 1972.

33. Barry E. M., Knight S. A. and Acker J. E. Jr. Hospital program for cardiac rehabilitation. Am. J. Nurs. 72. 2174, 1972.

34. Bastiaans J. Psychoanalytic investigations on the psychic aspects of acute myocardial infarction. Psychother. Psychosom. 16. 202, 1968.

35. Berg-Larsen R. A psychodynamic evaluation of patients with myocardial infarction with regard to their future occupational and social adjustments. $P_{s y}$ chother. Psychosom. 18. 294, 1970.

36. Bishop L. F. and Reichert P. The psychological impact of the coronary care unit. Psychosomatics 10. $189,1969$.

37. Bishop L. F. and Reichert P. Emotions and heart failure. Psychosomatics 12. 1971.

38. Bishop C. F. The psychological rehabilitation of the patient after a myocardial infarction. Singapore med. J. 14. 381, 1973.

39. Borgman M. F. Coronary rehabilitation-a comprehensive design. Int. J. nurs. Stud. 12. 13, 1975.

40. Cames G. D. Understanding the cardiac patient's behavior. Am. J. Nurs. 71. 1187, 1971 .

41. Cassem N. H., Hackett T. P., Bascom C. et al. Reactions of coronary patients to the CCU nurse. Am. J. Nurs. 70. 319, 1970.

42. Cassem N. H. and Hackett T. P. Psychological rehabilitation of myocardial infarction patients in the acute phase. Heart and Lung 2. 382, 1973.

43. Fejfar Z. Proglems and challenges in rehabilitation of patients with acute myocardial infarction. Schweiz. med. Wschr. 103. 35, 1973.

44. Foster S. and Andreoli K. G. Behavior following acute myocardial infarction. Am. J. Nurs. 70. 2344, 1970.

45. Groden B. M. and Cheyne A. I. Rehabilitation after cardiac illness. Br. med. J. 2. 700, 1972.

46. Hackett T. P., Cassem N. H. and Wishnie H. Detection and treatment of anxiety in the coronary care unit. Am. heart J. 78. 727, 1969.

47. Holub N., Eklund P. and Keenan P. Family conferences as an adjunct to total coronary care. Heart and Lung 4. 767, 1975.

48. Houser D. Outside the coronary care unit. Nurs. Forum 12. 96, 1973.

49. Kellerman J. J. Rehabilitation following myocardial infarction. Ind. J. Pediat. 39.126, 1972.

50. Kos B. A. The nurse's role in rehabilitation of the myocardial infarction patient. Nurs. Clin. N. Am. 4. $593,1969$.

51. Layman W. A. Psychologic impact of a coronary care unit. J. med. soc. N.J. 69. 1001, 1972.

52. Lee R. E. and Ball P. A. Some thoughts on the psychology of the coronary care unit patient. Am. J. Nurs. 75. 1498, 1975.

53. Lenzner A. S. Psychiatry in the coronary care unit. Psychosomatics 15. 70, 1974.

54. Nixon P. G. F. Recovery from coronary illness. Rehabilitation 81. 23, 1972.

55. Nixon P. G. F. Rehabilitation of the coronary patient Physiotheraphy 58. 336, 1972. 
56. Nixon P. G. F. and Bethell H. J. N. Preinfarction ill health. Am. J. Card. 33. 446, 1974.

57. Rahe R. H. Liaison psychiatry on a coronary care unit. J. hum. Stress 1. 13, 1975.

58. Royle J. Coronary patients and their families receive incomplete care. Can. Nurse 1. 21, 1973.

59. Semmler C. and Semmler M. Counseling the coronary patient. Am. J. occup. Ther. 28. 609, 1974.

60. Shah V. V. and Shah C. V. Cardiac rehabilitation Indian heart J. 24. 4, 1972.

61. Shah V. V. Heart disease-prevention and rehabilitation. Ind. J. chest Dis. 14. 119, 1972.

62. Smith C. A. Body image changes after myocardial infarction. Nurs. Clin. N. Am. 7.663, 1972.

63. Sobel D. E. Personalization on the coronary care unit. Am. J. Nurs. 69. 1439, 1969.

64. Warshaw L. L. Placing and managing the cardiac patient. Int. J. occup. Hith Saf. 43, 16, 1974.

65. White E. H. Beneath the tubes, behind the monitor. J. Pract. Nurs. 25, 20, 1975.

66. Adsett C. A. and Brohn J. G. Short-term group psychotherapy for post-myocardial infarction patients and their wives. Can. med. Ass. J. 99. 577, 1968.

67. Bilodeau C. B. and Hackett T. P. Issues raised in a group setting by patients recovering from myocardial infarction. Am. J. Psychiat. 128, 105, 1971.

68. Idelson R. K., Croog S. H. and Levine S. Changes in self-concept during the year after a first heart attack: a natural history approach-part I. Am. archs rehab. Ther. 22. 10, 1974.

69. Idelson, R. K., Croog S. J. and Levine S. Changes in self-concept during the year after a first heart attack: a natural history approach-part II. Am. archs rehab. Ther. 22. 25, 1974.

70. Karstens R., Kohle K., Ohlmeier D. et al. Multi-disciplinary approach for the assessment of psychodynamic factors in young adults with acute myocardial infarction. Psychother. Psychosom. 18. 281, 1970.

71. Klein R. F. Kliner, V. A., Zipes D. P. et al. Transfer from a coronary care unit. Archs intern. Med. 122. 104. 1968.

72. Lenzner A. S. and Aronson A. L. Psychiatric vignettes from a coronary care unit. Psychosomatics 13. 179. 1972.

73. Mone L. C. Short-term psychotherapy with post-cardiac patients. Int. J. Grp. Psychother. 20. 99, 1970.

74. Ohlmeier D., Karstens R. and Kohle K. Psycho-analytic group interview and short-term group psychotherapy with post-myocardial infarction patients. Psychiat. Clin. 6. $240,1973$.

75. Rahe R. H., Tuffli C. F. Jr., Suchor R. J. Jr. et al. Group therapy in the outpatient management of postmyocardial infarction patients. Psychiat. Med. 4. 77. 1973.

76. Skelton M. and Dominian J. Psychological stress in wives of patients with myocardial infarction. $\mathrm{Br}$, med. J. 2. $101,1973$.

77. Tyzenhouse P. S. Myocardial infarction: its effect on the family. Am. J. Nurs. 73, 1012, 1973.

78. Ibrahim M. A., Feldman J. G., Sultz H. A., Staiman M. G., Young L. J. and Dean D. Management after myocardial infarction: a controlled trial of the effect of group psychoterapy. Int. J. psychiat. Med. 5. 253, 1974.

79. Thockloth R. M. Ho S. C.. Wright H. et al. Is cardiac rehabilitation really necessary? Med. J. Aust. 2. 669. 1973.

80. Greene W. A. Psychosocial considerations in the conduct of intervention treatment trials. J. S. Carol. med. Ass. 45, 1976.

81. Gruen W. Effects of brief psychotherapy during the hospitalization period on the recovery process in heart attacks. J. con. clin. Psychol. 43. 223, 1975.
82. Hahn P. and Leisner R. The influence of biographical anamnesis and group psychotherapy on post-myocirdial patients. Pstchother. Psichosom. 18. 299. 1970.

83. Ibrahim M. A. The impact of intervention upon psychosocial functions of post-mycardial infarction patients. J. S. Carol med. Ass. 23. 1976.

84. Oliver M. F. From data cited by Bondurant S. Sumposium on the pre-hospital phase of acute myocardial infarction. Rochester. New York. 17-18 May 1969. Am. J. Card. 24. 612. 1969

85. Goldstein S., Moss A. J. and Greene W. Sudden death in acute myocardial infarction. Archs intern. Med. 129. $720,1972$.

86. Hackett T. P. and Cassem N. H. Factors contributing to delay in responding to the signs and symptoms of acute myocardial infarction. Am. J. Cart. 24. 651. 1969.

87. Moss A. J.. Wynar B. and Goldstein S. Delay in hospitalization during the acute coronary period. $4 \mathrm{~m} . \mathrm{J}$. Card. 24. 659. 1969.

88. Moss A. J. and Goldstein S. The pre-hospital phase of acute myocardial infarction. Circulation 41. 737. 1970.

89. Simon A. B.. Feinleib M. and Thompson H. K. Jr. Components of delay in the pre-hospital phase of acute myocardial infarction. Am. J. Card. 30. 476. 1972.

90. Simon A. B., Alonzo A. A. and Feinleib M. Patient response to acute episodes of coronary heart disease. Archs intern. Med. 133. 824, 1974.

91. Feinleib M. and Davidson M. J. Coronary heart disease mortality. J. Am. med. Ass. 222. 1129.1972.

92. Cassem N. H., Wishnie H. A. and Hackett T. P. How coronary patients respond to last rites. Postgrad. Med. 45. 147, 1969.

93. Hackett T. P., Cassem N. H. and Wishnie H. A. The coronary-care unit: an appraisal of its psychologic hazards. N. Engl. J. Med. 279. 1365. 1968.

94. Bruhn J. G.. Thurman A. E. Jr., Chandler B. C. et al. Patients" reactions to death in a coronary care unit. J. psychosom. Re's. 14. 65, 1970.

95. Graham L. E. Patients' perceptions in the CCU. Am J. Nurs. 69. 1921, 1969.

96. Cay E. L., Vetter N. J.. Philip A. E. et al. Psychological reactions to a coronary care unit. Scand. J, rehabil. Med. 23. 78, 1970.

97. Dominian J. and Dobson M. Study of patients' psychological attitudes to a coronary care unit. $\mathrm{Br}$. med. J. 4. 795, 1969.

98. Parker D. L. and Hodge J. R. Delirium in a coronary care unit. J. Am. med. Ass. 201. 132. 1967.

99. Leigh H., Hofen M. A.. Cooper J. and Reiser M. F A psychological comparison of patients in "open" and "closed" coronary care units. $J$. psychosom. Re's. 16. 449, 1972.

100. Cassem N. H. and Hackett T. P. Psychiatric consultation in a coronary care unit. Alm. intern. Med. 75. 9. 1971

101. Cay E. L., Vetter N.. Philip A. E. et al. Psychological status during recovery from an acute heart attack. J. psychosom. Res. 16. 425.1972.

102. Gentry W. D.. Foster S. and Haney T. Denial as a determinant of anxicty and perceived health status in the coronary care unit. Psychosom. Med. 34. 39. 1972.

103. Froese A., Hackett T. P.. Cassem N. H. et al. Trajectories of anxiety and depression in denying and nondenying acute myocardial infarction patients during hospitalization. $J$. psichosom. Res. 18, 413 1974.

104. Miller W. B. and Rosenfeld R. A. Psychophysiological study of denial following acute myocardial infarction. J. psychosom. Res. 19. 43, 1975. 
105. Croog S. H. Shapiro D. S. and Levine S. Denial among heart patients. Psychosom. Med. 33. 385, 1971.

106. Cattell R. M. Handbook for Sixteen Personality Factor Questionnaire. Chicago Institute for Personality and Ability Testing. 1954 .

107. Hackett T. P. and Cassem N. H. Development of a quantitative rating scale to assess denial. J. psychosom. Res. 18. 93. 1974.

108. Froese A.. Vasquez E., Cassem N. H. et al. Validation of anxiety. depression and denial scales in a coronary care unit. J. psychosom. Res. 18. 137, 1974.

109. Holland J.. Sgroi S., Marwit S. et al. The ICU syndrome: fact or fancy? Psychiat. Med. 4. 241, 1973.

110. Froese A. P.. Cassem N. H., Hackett T. P. et al. Galvanic skin potential as a predictor of mental status, anxicty. depression and denial in acute coronary patients. J. psychosom. Res. 19. 1. 1975.

111. Hackett T. P. and Weisman A. D. Denial as a factor in patients with heart disease and cancer. Ann. N.Y. Acad. Sci. 164. 802. 1969.

112. Levine J. and Zigler E. Denial and self-image in stroke, lung cancer and heart disease patients. $J$. con. clin. Psychol. 43. 751, 1975.

113. Hackett T. P. and Cassem N. H. Psychological adaptation to convalescence in myocardial infarction patients. In Exercise Testing and Exercise Training in Coronary Heart Disease (Edited by Naughton J. and Hellerstein H. K.). p. 253. Academic Press, New York, 1973.

114. Croog S. H. and Levine S. Social status and subjective perceptions of $\mathbf{2 5 0}$ men after myocardial infarction. Publ. Hith Repts 84. 989, 1969.

115. Brown L. B., Antic R. and Hetzel B. S. Social effects of myocardial infarction in men under the age of 50 years: a review after one to eight years. Med.J. Aust. 2. 125,1969

116. Bruhn J. G., Chandler B. and Wolf S. A psychological study of survivors and nonsurvivors of myocardial infarction. Psychosom. Med. 3. 8, 1969.

117. Bruhn J. G.. Wolf S. and Philips B. U. A psychosocial study of surviving male coronary patients and controls followed over nine years. $J$. psychosom. Res. 15. 305.1971.

118. Croog S. H. and Levine S. Religious identity and response to serious illness: a report on heart patients. Soc. Sci. Med. 6. 17, 1972.

119. Croog S. H., Lipson A. and Levine S. Help patterns in severe illness: the roles of kin network, non-family resources, and institutions. J. Marriage Family 34. 32, 1972.

120. Garrity T. F. Social involvement and activeness as predictors of morale six months after first myocardial infarction. Soc. Sci. Med. 7. 199, 1973.

121. Hellerstein H. K. and Friedman E. H. Sexual activity and the post-coronary patient. Archs intern. Med. 125. 987. 1970.

122. Hinohara S. Psychological aspects in rehabilitation of coronary heart disease. Scand J. rehabil. Med. 2-3. 53. 1970

123. Josten J. Emotional adaptation of cardiac patients. Scand. J. rehabil. Med. 2-3. 49, 1970.

124. Kavanagh T., Shephard R. J. and Tuck, J. A. Depression after myocardial infarction. Can. med. Ass. J. 113. 23. 1975 .

125. McGrath F. J. and Robinson J. C. The medical social worker in the coronary care unit. Med. J. Aust. 2. 1113. 1973.

126. Mordkoff A. M. and Rand M. A. Personality and adaptation to coronary artery disease. J. con. clin. Psichol. 32. 648, 1968.

127. Rahe R. J. and Paasikivi J. Psychosocial factors and myocardial infarction-II. An outpatient study in Sweden. J. psychosom. Res. 15. 33. 1971.
128. Rodda B. E., Miller N. C. III and Bruhn J. G. Prediction of anxiety and depression patterns among coronary patients using a Markov process analysis. Behav. Sci. 16. 482. 1971 .

129. Ruskin H. D., Stein L. L., Shelsky I. M. et al. MMPI comparison between patients with coronary heart disease and their spouses together with other demographic data. Scand. J. rehabil. Med. 2-3. 99,1970

130. Weinblatt E., Shapiro S. and Frank C. W. Changes in personal characteristics of men, over five years following first diagnosis of coronary heart disease. $\mathrm{Am}$ J. publ. Hlth 61. 831, 1971.

131. Wishnie H. A., Hackett T. P. and Cassem N. H Psychological hazards of convalescence following myocardial infarction. J. Am. med. Ass. 215. 1292. 1971.

132. Wynn A. Unwarranted emotional distress in men with ischaemic heart disease. Med. J. Aust. 2. 347 , 1967.

133. Dahlstrom W. G. and Welsh G. S. An MMPI Handbook. Minneapolis, University of Minnesota Press, 1960.

134. Anderson D. E. and Schiller E. Assessing the value of early rehabilitation after myocardial infarction. Singapore med. J. 14. 372, 1974.

135. Schiller E. and Morris G. Coronary disease and return to work. Med. J. Aust. 1. 889, 1971.

136. Fisher S. Impact of physical disability on vocational activity: work status following myocardial infarction. Scand. J. rehabil. Med. 2-3. 65, 1970.

137. Garrity T. F. Vocational adjustment after first myocardial infarction: Comparative assessment of several variables suggested in the literature. Soc. Sci. Med. 7. $705,1973$.

138. Groden B. M. Return to work after myocardial infarction. Scott. med. J. 12. 297, 1967.

139. Hay D. R. and Turbott S. Rehabilitation after myocardial infarction and acute coronary insufficiency. $N$. Z. med. J. 71. 268, 1970.

140. Hay D. R., Weir C. J. and McGregor M. R. Further observations on cardiac rehabilitation. N. Z. med. J. 78. $478,1973$.

141. Higgins A. C. and Pooler W. S. Myocardial infarction and subsequent reemployment in Syracuse, New York. Am. J. publ. Hith 58. 312, 1968.

142. Kellerman J. J., Modan B., Levy M. et al. Return to work after myocardial infarction. Geriatrics 23. $151,1968$.

143. Monteiro L. A. Lay views on activity after myocardial infarction. Rhode Isl. med. J. 55. 77, 1972.

144. Monteiro L. A. After heart attack: behavioral expectations for the cardiac. Soc. Sci. Med. 7. 555, 1973.

145. Mulcahy R., Hickey N. and Coghlan N. Rehabilitation of patients with coronary heart disease. Geriatrics 3. 120, 1972.

146. Nagle R., Gangola R. and Picton-Robinson I. Factors influencing return to work after myocardial infarction. Lancet 2. 454, 1971

147. Shapiro S., Weinblatt E. and Frank C. W. Return to work after first myocardial infarction. Archs envir. Hith 24. 17, 1972.

148. Weinstock M. and Haft J. I. The effect of illness on employment opportunities. Archs envir. Hith 29. 79 , 1974.

149. Dohrenwend B. S. and Dohrenwend B. P. Stressful Life Events. Wiley, New York, 1974.

150. Bartle S. H. and Bishop L. F. Psychological study of patients with coronary heart disease with unexpectedly long survival and high level function. Psychosom. $15.68,1974$.

151. Croog S. H. and Levine S. Social aspects of rehabilitation. Med. Insight 5. 10, 1973.

152. Geismar P., Iversen E.. Mosbech J. et al. Long-term 
survival after myocardial infarction: a national follow-up study on 642 patients in Denmark. Int. J. Epidem. 2. 257. 1973.

153. Hrubec $Z$. and Zukel W. J. Socioeconomic differentials in prognosis following episodes of coronary heart disease. J. chron. Dis. 23. 881. 1971.

154. Shapiro S., Weinblatt E., Frank C. W. et al. Social factors in the prognosis of men following first myocardial infarction. Millbank meml. Fund q. Bull. 48. 37. 1970.

155. Weinblatt E., Shapiro S.. Frank C. W. et al. Prognosis of men after first myocardial infarction: mortality and first recurrence in relation to selected parameters. $\mathrm{Am}$. J. publ. Hith 58. 1329. 1968.

156. Frank C. W.. Weinblatt E., Shapiro S. et al. Prognosis of men with coronary heart disease as related to blood pressure. Circulation 38. 432, 1968.

157. Woodhouse S. P. Subsequent mortality in patients surviving myocardial infarction. N. Z. med. J. 69. 24. 1969.

158. Bierenbaum M. L., Fleischman A. I., Raichelson R. I. et al. Ten-year experience of modified-fat diets on younger men with coronary heart disease. Lancet 3. 1404, 1973.

159. Coronary Drug Research Project Group: Factors influencing long-term prognosis after recovery from myocardial infarction - three year findings of the Coronary Drug Project. J. chron. Dis. 27. 267, 1974.

160. Kentala E., Pyorala K., Heikkila J. et al. Factors related to long-term prognosis following acute myocardial infarction. Scand. J. rehabil. Med. 7. 118, 1975.

161. Moss A. J.. DeCamilla J., Engstrom F. et al. The posthospital phase of myocardial infarction. Circulation 49. $460,1974$.

162. Mulcahy R., Hickey N., Graham I. et al. Factors influencing long-term prognosis in male patients surviving a first coronary attack. Br. heart J. 37. 158, 1975.

163. Norris R. M., Caughey D. E., Deeming L. W. et al Coronary prognostic index for predicting survival after recovery from acute myocardial infarction. Lancet 2. 485, 1970.

164. Norris R. M., Caughey D. E., Deeming L. W. et al. Prognosis following acute myocardial infarction. $N$. Z. med. J. 77. 12. 1973.

165. Shanoff H. M., Little J. A. and Csima A. Studies of male survivors of myocardial infarction: XII. Relation of serum lipids and lipoproteins to survival over a 10-year period. Can. med. Ass. J. 103. 927. 1970.

166. Zukel W. J., Cohen B. M., Mattingly T. W. et al. Survival following first diagnosis of coronary heart disease. Am. heart J. 78. 159. 1969.

167. Jenkins C. D. Psychologic and social precursors of coronary heart disease. N. Engl. J. Med. 284. 244 , 1971.

168. Groden B. M., Allison A. and Shaw G. B. Management of myocardial infarction-the effect of early mobilization. Scott. med. J. 12. 435.1967.

169. Groden B. M. and Brown R. I. F. Differential psychological effects of early and late mobilization after myocardial infarction. Scand. J. rehabil. Med. 2-3.80, 1970 .

170. Naughton J., Bruhn J. G. and Lategola M. T. Effects of physical training on physiologic and behavioral characteristics of cardiac patients. Archs phys. med. Rehahil. 49. 131, 1968.

171. Kavanagh T.. Shephard R. J., Pandit V. et al. Exercise and hypnotherapy in the rehabilitation of the coronary patient. Archs phys. med. Rehabil. 51. 578. 1970.
172. Kavanagh $T$. and Shephard R. J. Importance of physical activity in post-coronary rehabilitation. $A \mathrm{~m}$. J. phys. Med. 52. 304. 1973.

173. Heinzelmann F. Social and psychological factors that influence the effectiveness of exercise programs. In Exercise Testing and Exercise Training in Coronary Heart Disease (Edited by Naughton J. and Hellerstein H. K.). p. 275. Academic Press. New York. 1973.

174. Bloch A. Maeder J. and Haissly J. Sexual problems after myocardial infarction. Am. hear J. 90. 536. 1975.

175. Croog S. J.. Koslowsky M. and Levine S. Personality self-perceptions of male heart patients and their wives: issues of congruence and "coronary persona. lity." Unpublished manuscript.

176. Suinn R. M.. Brock L. and Edie C. A. Behavior therapy for Type A patients. Am. J. Card. 36. 269. 1975.

177. Theorell T. and Rahe R. J. Psychosocial factors and myocardial infarction- $-\mathrm{I}$. An inpatient study in Sweden. J. psychosom. Res. 15. 25. 1971

178. Theorell T. and Rahe R. J. Behavior and life satisfactions characteristic of Swedish subjects with myocardial infarction. J. chron. Dis. 25. 139, 1972.

179. Van der Valk J. M. and Groen J. J. Personality structure and conflict situation in patients with myocardial infarction. J. psychosom. Res. 11. 41. 1967.

180. Wardwell W. I. and Bahnson C. B. Behavioral variables and myocardial infarction in the southeastern Connecticut heart study. J. chront. Dis. 26. 447, 1973.

181. Bruhn J. G. Obtaining and interpreting psychosocial data in studies of coronary heart disease. In Exercise Testing and Exercise Training in Coronary Heart Disease (Edited by Naughton J. and Hellerstein H. K.). p. 263. Academic Press. New York, 1973.

182. Norris R. M., Brandt P. W. T., Caughey D. E. et al. A new coronary prognustic index. Lancet 1. 274. 1969.

183. The President's Committee on Employment of the Handicapped. Proceedings of the Cardiac SeminarFebruary 6-7 1975. U.S. Government Printing Office: 0-210-882 (49), 1975.

184. Proceedings of the National Heart and Lung Institute Working Conference on Health Behavior. 12-15 May 1975. DHEW Publication No. (NIH) 76-868.

185. Croog S. H. Problems of barriers in the rehabilitation of heart patients: social and psychological aspects. Cardiac Rehubilitation 6. 27, 1975.

186. Needs and opportunities for rehabilitating the coronary heart disease patient (DHEW Publication No. [NIH] 75-750). Washington. D.C.. U.S. Government Printing Office, 1974.

187. Evaluation of comprehensive rehabiliative and preventative programmes for patients after acute myocardial infarction (World Health Organization. EURO 8206 [8]). Copenhagen. Denmark. Regional Office for Europe. 1973.

188. Wright I. S. Cardiovascular disease-unanswered questions. Circulation 47. A341. 1973.

189. Fisher S. International survey on the psychological aspects of cardiac rehabilitation. Scand. J. rehabil. Med. 2-3. 71, 1970.

190. Fisher S. Unmet needs in psychological evaluation of intervention programs. In Exercise Testing and Exercise Training in Coronary Heart Disease (Edited by Naughton J. and Hellerstein H. K.). p. 289. Academic Press. New York. 1973.

191. Joint Working Party: Cardiac rehabilitation 1975. J. R. Coll. Phys. Lond. 9. 281. 1975 